\title{
Elaboration of mangaba vinegar by semi-solid fermentation combined with enzymatic activity: chemical characterization and sensory evaluation
}

\author{
Ana Elisa Barbosa Siqueira ${ }^{1}$ Elaine Pilati da Silva ${ }^{1}$ Emanuelle dos Santos Santiago ${ }^{1}$ (iD \\ Érico Tasso Leite Barros Teixeira ${ }^{1}$ (i) Juliana de Andrade Mesquita ${ }^{1}(\mathbb{D}$

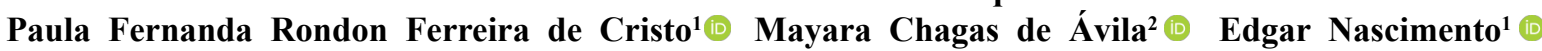 \\ Wilma Aparecida Spinosa $^{3}$ (i) Demétrio de Abreu Sousa ${ }^{1^{*}}$ (i)
}

\begin{abstract}
${ }^{1}$ Instituto Federal de Educação, Ciência e Tecnologia de Mato Grosso (IFMT), Campus Cuiabá, 78050-560, Cuiabá, MT, Brasil. E-mail: demetrio.sousa@blv.ifmt.edu.br. "Corresponding author.

${ }^{2}$ Faculdade de Engenharia de Alimentos, Universidade Estadual de Campinas (Unicamp), Campinas, SP, Brasil.

${ }^{3}$ Departamento de Ciência e Tecnologia de Alimentos, Universidade Estadual de Londrina (UEL), Londrina, PR, Brasil.

ABSTRACT: The objective of this study was to produce vinegar from mangaba pulp using semi-solid alcoholic fermentation combined with the enzymatic activity of pectinase and to investigate the chemical composition and sensory characteristics of the final product. was evaluated for volatile acidity and the reduced dry extract was evaluated for ashes, alcohol content, sulfates, pH, total phenolic compounds, total carotenoids, color parameters, yield, productivity, and sensory analysis. Average and standard deviation was used for descriptive statistics. Principal component analysis (PCA) was applied to all variables except total carotenoid content. Physicochemical characterization of the raw and alcoholically fermented pulp was also carried out. The main results showed that, in the vinegar, the reduced dry extract, volatile acidity, $\mathrm{pH}$, and ashes were $44.3 \pm 1.5(\mathrm{~g} / \mathrm{L}), 4.4 \pm 0.1(\% \mathrm{w} / \mathrm{v}), 3.1 \pm 0.0$, and $3.0 \pm 0.41(\mathrm{~g} / \mathrm{L})$, respectively. The total phenolic compound content and total carotenoid content for the mangaba vinegar were $19.2 \pm 8.20 . \mathrm{mg} / 100 \mathrm{~g}$ and $2.6 \pm 0.6 . \mathrm{mg} / 100 \mathrm{~g}$, respectively. The conversion yield from ethanol to acetic acid was $90 \%$. PCA showed that pH and volatile acidity had a strong influence on the product, and there was a strong positive correlation between color and aroma. The final product met all legal requirements, showing that it is possible to produce mangaba vinegar with antioxidant potential for consumers. In the sensory evaluation, it was favored by the tasters, demonstrating potential economic value in the Cerrado fruit.

Key words: cerrado's fruit, fermented beverages, semi-solid fermentation, pectinase, main components.
\end{abstract}

Elaboração de vinagre de mangaba por fermentação semi-sólida com ação enzimática: caracterização química e avaliação sensorial

RESUMO: Objetivou-se produzir vinagre, a partir da polpa de mangaba por fermentação alcoólica semi-sólida com ação enzimática através da pectinase, investigar a composição química e avaliação sensorial do produto final. O vinagre foi avaliado através da acidez volátil, extrato seco reduzido, cinzas, teor alcoólico, sulfatos, $\mathrm{pH}$, compostos fenólicos totais, carotenoides totais, parâmetros de cor, rendimento, produtividade e análise sensorial. Os dados foram submetidos a estatística descritiva com média e desvio padrão. Foi aplicado a análise de componentes principais (ACP) para todas as variáveis, exceto para análise de carotenoides totais. Também foi realizada a caracterização fisico-química da polpa e fermentado alcoólico. Os principais resultados mostraram que, no vinagre, extrato seco reduzido, acidez volátil, pH e cinzas foram, respectivamente, 44,3 $\pm 1,5(\mathrm{~g} / \mathrm{L}), 4,4 \pm 0,1(\% \mathrm{~m} / \mathrm{v}), 3,1 \pm 0,0,3,0 \pm 0,41(\mathrm{~g} / \mathrm{L})$. Os compostos fenólicos totais e carotenoides

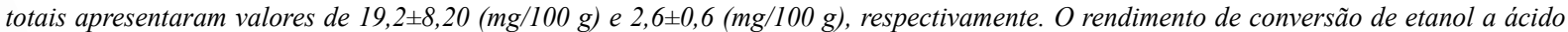
acético foi de $90 \%$. ACP foi aplicada nas variáveis físico-químicas do vinagre no qual os parâmetros de cor, pH e acidez volátil apresentaram forte influência no produto e, para os atributos da análise sensorial, cor e aroma apresentaram uma forte correlação positiva entre si. $O$ produto final atendeu a todos os quesitos legais, demonstrando ser possível a produção de vinagre de mangaba com potencial antioxidante. Na avaliação sensorial teve boa aceitação pelos provadores, valorizando o uso deste fruto do Cerrado.

Palavras-chave: fruto do cerrado, bebidas fermentadas, fermentação semissólida; pectinase; componentes principais.

\section{INTRODUCTION}

Vinegar is a common food product that is widely available on the market. There are several types of vinegar depending on the raw material it is fermented from. It is usually made from fruit juices, starchy tubers, cereals, sugary raw materials, and alcohol (AQUARONE et al., 2001; BRASIL, 2009a; HO et al., 2017). Normative Instruction 06/2012 (BRAZIL, 2012a) establishes the identity and quality 
standards for acetic acid fermentation that can be designated as vinegar as long as the vegetable origin of the raw material is stated. The vinegar may also contain optional ingredients such as herbs, spices, concentrated juices, and honey (FDA, 1980; FDA, 1989; CAC, 2000; BRASIL, 2009a).

There are two main biotechnological processes involved in the production of vinegar: (1) alcoholic fermentation in the presence of yeast (Saccharomyces cerevisiae) and (2) acetic acid oxidation in the presence of acetic acid bacteria belonging to the generaAcetobacter, Gluconacetobacter, Gluconobacter, and Komagataeibacter (TANNER, 1944; HO et al., 2017; GOMES et al., 2018). Any substrate that contains sugars and nitrogenous food stores can be fermented to acetic acid. Vinegars are made from lemon juice (LEONÉS et al., 2019), acerola (PINO et al., 2019), pineapple (RODA et al., 2017), black raspberry (SONG et al., 2018), bergamot (GIUFFRÈ et al., 2019), and blackberry (CUNHA et al., 2016).

The fruits native to the Brazilian Cerrado, despite their exotic flavors, are characterized by the low total sugar content (SILVA et al., 2008) in fruits such as cagaita $(3.08 \%)$, cerrado cashew $(6.97 \%)$, murici $(5.96 \%)$, araçá $(7.67 \%)$, and mangaba (10.02\%). Fermentable sugars, such as glucose, are important for a good yield of ethanol production. However, these fruits have large amounts of non-fermentable sugars (polysaccharides) requiring technological applications, such as the use of enzymes, for the release of fermentable sugars (SANTOS et al., 2012).

Mangaba (Hancornia speciosa Gomes) is the fruit of the mangabeira and is native to several regions of Brazil such as the cerrado, tabuleiros costeiros, chapadas, and caatingas (PERFEITO et al., 2015; PEREIRA et al., 2016). Its pulp, which has a characteristic and pleasant flavor, is commonly used in products such as juices, popsicles, ice cream, jams, jellies, and liquor (PEREIRA et al., 2016). It contains vitamins $\mathrm{C}$ and $\mathrm{E}$, minerals, and $\beta$-carotene, in addition to possessing significant antioxidant capacity (FRANCO, 1992; CARDOSO et al., 2014; PEREIRA et al., 2015; NARAIN et al., 2018). However, when the mangaba fruit reaches a degree of ripeness, it detaches from the plant and falls. This compromises the quality as complete ripening occurs a few hours afterward, which can result in the loss of fermentable materials due to the extremely thin skin of the fruit (VIEIRA NETO, 2001; PERFEITO et al., 2015).

This fruit can be used for making vinegar. Recently, demand for fruit vinegars has increased, driven in part by their reputation as a healthy food product that is rich in volatile compounds, such as short-chain organic acids and esters, in addition to amino acids, vitamins, polyphenols, and flavorings, which are also provide health benefits (HO et al., 2017; DONNA et al., 2020).

The pulp of the mangaba has a fleshyviscous consistency, probably due to the presence of pectic substances, thus characterizing it as a semi-solid matrix. Vinegar production from this fruit is therefore a challenge, and the use of the enzyme pectinase is an alternative to enable alcoholic fermentation in a semi-solid matrix. Pectinolytic enzymes assist in the extraction of aromatic components and increase alcohol yield, as the hydrolysis of pectin increases the amount of reducing sugars available for fermentation in the medium (LEONEL et al., 2015; SPINOSA et al., 2016; RODA et al., 2017).

In Brazil, the most popular vinegar types are from wine, apple, rice, and alcohol. However, fruit vinegars, especially those from tropical fruits, are still unknown to most of the Brazilian population. The objective of this work was to produce vinegar from mangaba pulp using semi-solid alcoholic fermentation with enzymatic degradation using pectinase and to investigate the chemical composition and sensory characteristics of the final product.

\section{MATERIALS AND METHODS}

\section{Materials}

Mangaba pulp was purchased from the agricultural extractivist-cooperative Grande Sertão and stored at $-18{ }^{\circ} \mathrm{C}$ until use. Lyophilized yeast Saccharomyces cerevisiae Y 904 (Fleishman $^{\circledR}$ ) was used for alcoholic fermentation. Pectinase in the form of Endozym ${ }^{\circledR}$ Rouge Liquid mixture was provided by the vinegar company, located in São Paulo. An inoculum of a mixed culture of acetic acid bacteria, originating from an unpasteurized organic commercial apple vinegar, was used for acetic oxidation, (Lot 17D3, Montes Verdes ${ }^{\circledR}$ Brazil).

\section{Preparation of mangaba vinegar}

The process of making vinegar from the mangaba is outlined in figure 1. Physicochemical analysis was performed for the mangaba pulp, which was soluble in ${ }^{\circ}$ Brix (method 315 / IV), using a Toledo $^{\circledR}$ refractometer (model RM 40, Brazil); pH (method 017 / IV) was determined using a digital $\mathrm{pH}$ meter (model 2221; HANNA ${ }^{\circledR}$, USA); and reducing sugar was quantified by spectrophotometry (model Genysys 6, Thermo ${ }^{\circledR}$, USA). Quantification of the alcohol content and total acidity (method 504 / IV) 


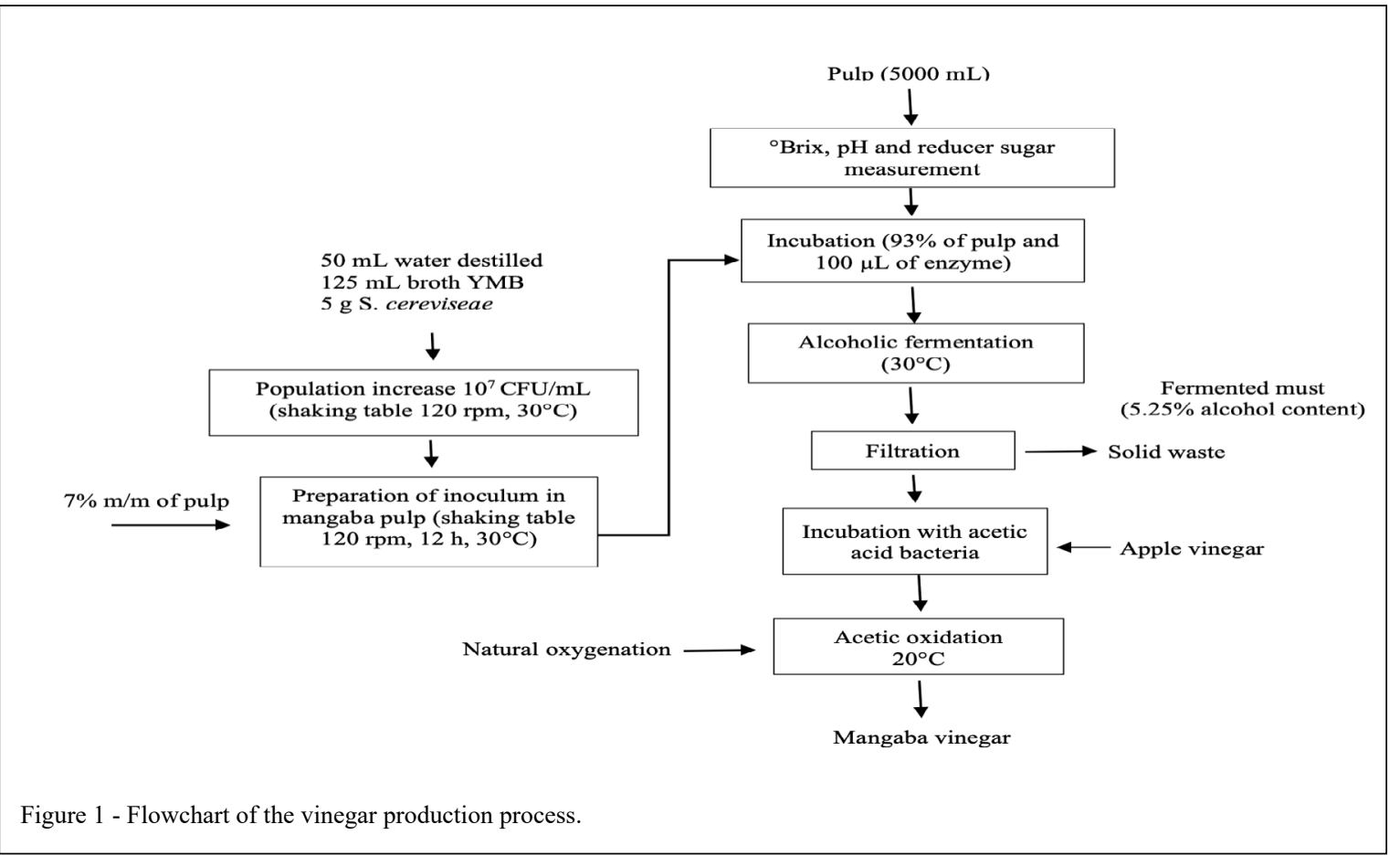

of mangaba vinegar was also performed. All analyses were carried out in triplicate and followed the standards of the Adolfo Lutz Institute (IAL, 2008), except for the analysis of reducing sugars (EMBRAPA, 2013) and alcohol content (ABNT, 1997).

The inoculum was prepared using activated yeast in yeast mannitol broth (YMB) and was monitored by counting in a Neubauer chamber (New Optik $^{\circledR}$, Improved model, Italy) until a population of $1 \times 10^{7} \mathrm{CFU} / \mathrm{mL}$ was reached, according to SPINOSA et al. (2016).

Initially, $5 \mathrm{~g}$ of the activated inoculum was added to $350 \mathrm{~g}(7 \%)$ of the mangaba pulp. After $12 \mathrm{~h}$, the remaining $93 \%$ of the pulp and $100 \mu \mathrm{L}$ of the enzyme mixture were added to a bioreactor (BioFoco $^{\circledR}$, model Rubia basic, Brazil) under anaerobic conditions at $30{ }^{\circ} \mathrm{C}$ (Figure 1). Alcohol content was monitored by taking $100 \mathrm{~mL}$ aliquots after $96 \mathrm{~h}$ and $168 \mathrm{~h}$. When the alcohol content was constant, fermentation was ended.

A sample of $8 \mathrm{~mL}$ of alcoholic fermented mangaba was added to $24 \mathrm{~mL}$ of vinegar (Montes Verdes ${ }^{\circledR}$ ) to acclimatize the acetic acid bacteria in order to obtain the inoculum that initiates acetic acid oxidation (AQUARONE et al., 2001). The reaction took place at $20{ }^{\circ} \mathrm{C}$ under aerobic conditions until the total acid content of the vinegar reached $5 \% \mathrm{w} / \mathrm{v}$. Therefore, each oxidation step was carried out by adding the mixture at a ratio of 1:3 (volume of alcoholic fermented mangaba: product volume with $5 \% \mathrm{w} / \mathrm{v}$ of total acidity), which constitutes the first stage, successively five times until reaching a volume of $100 \mathrm{~mL}$.

Considering the initial and final concentration of each stage, a constant value of 1.33 was found for the concentration cycle of the stages calculated by equation 1 . The time for each stage was approximately $72 \mathrm{~h}$.

Concentracion cycle $=\frac{\text { final concentration of acetic acid }}{\text { inicial concentration of acetic acid }}$

\section{Physicochemical analysis}

The analysis of total soluble solids (SST) (method $315 /$ IV), total acidity of fruits and fruit products (method 310 / IV and 312 / IV), total vinegar acidity (method 504 / IV), fixed acidity and volatile acidity (method 506 / IV), "Ratio" of total Brix/acidity (method 316 / IV), hydrogen potential (method 017 / IV), protein factor at 6.25 (method 36 / IV), total lipids by the Bligh-Dyer method (method 353 / IV), ashes (method 353 / IV), humidity (method 012 / IV), total dry extract (method 508 / IV), reduced dry extract (method 509 / IV), and sulfates (approximate method by Marty 241 / IV) were conducted according to IAL standards (2008). 


\section{Color parameters}

The color parameters red index $\left(\mathrm{a}^{*}\right)$, yellow index $\left(b^{*}\right)$, and luminosity $\left(\mathrm{L}^{*}\right)$ were obtained using a Konica Minolta ${ }^{\circledR}$ colorimeter (model CM-700d, Japan), calibrated with white standard CM-A177 and standard observer (D65 illuminant, $10^{\circ}$ ). The results were expressed using the CIELab system on the scale $\left(L^{*}, a^{*}\right.$, and $\left.b^{*}\right)$. The values of the saturation index $\left(\mathrm{C}^{*}\right)$ and angle hue $\left(\mathrm{h}^{*}\right)$ were obtained as described by RAMOS \& GOMIDE (2007).

\section{Water activity}

The water activity (aW) of the mangaba pulp was determined based on the dew point measurement, following AOAC methodology No. 978.18 (2012), by direct measurement using the Decagon ${ }^{\circledR}$ AQUALAB 4TE water analyzer (Meter, USA) and performed in triplicate.

\section{Alcohol content}

Alcohol content was determined in samples of alcoholically fermented pulp and mangaba vinegar using a Marconi ${ }^{\circledR}$ micro-distillatory (model MA 012, Brazil). The alcoholic distillate was obtained and alcohol content quantified using the UV-visible spectrophotometric method, with an ethanol standard curve (Lot AE29101RA, Exxodo ${ }^{\circledR}$, Brazil) according to technical standard (NBR 13920) and expressed in $\mathrm{mL} / 100 \mathrm{~mL}$ of the sample (ABNT, 1997).

\section{Determination of reducing sugars}

The reducing sugars from the raw and alcoholically fermented pulp were determined by the Somogyi-Nelson method and quantified using a spectrophotometer (model Geysys 6, Thermo ${ }^{\circledR}$, USA) at $540 \mathrm{~nm}$. D-glucose was used to construct the calibration curve (Lot 5Z13C120, SIGMA ${ }^{\circledR}$, Brazil). The results are expressed in $\mathrm{g} / 100 \mathrm{~g}$ of mangaba pulp and, for wine, expressed in $\mathrm{g} / 100 \mathrm{~mL}$ of sample (EMBRAPA, 2013).

\section{Determination of total sugar content}

The total sugar content in the mangaba pulp was quantified using a spectrophotometer (model Geysys 6, Thermo ${ }^{\circledR}$, USA) at $490 \mathrm{~nm}$, and a calibration curve was constructed with D-glucose standard (Lot 5Z13C120, SIGMA ${ }^{\circledR}$, Brazil). All analyses and results expressed in $\mathrm{g} / 100 \mathrm{~g}$ of mangaba pulp were proceeded as described by DUBOIS et al. (1956).

\section{Determination of phenolic compound content}

The content of total extractable phenolic compounds was determined using a spectrophotometer (model Geysys 6, Thermo ${ }^{\circledR}$, USA) at $700 \mathrm{~nm}$. Gallic acid was used to construct the calibration curve (Lot 66845, Dinâmica ${ }^{\circledR}$, Brazil) and the results were expressed in $\mathrm{mg} / 100 \mathrm{~g}$ of the sample (OBANDA \& OWUOR, 1997).

\section{Determination of total carotenoid content}

Amounts of $\alpha$-carotene and $\beta$-carotene were determined following the methodology described by PACHECO et al. (2011) using a spectrophotometer $\left(\right.$ Shimadzu $^{\circledR}$, model UV-1800, Japan) at $444 \mathrm{~nm}$ for $\alpha$-carotene and $453 \mathrm{~nm}$ for $\beta$-carotene. Petroleum ether was used as a blank. The total carotenoid content was calculated using the molar absorptivity values of $E_{1 \mathrm{~cm}}^{1 \%}=2800$ for $\alpha$-carotene and $E_{1 \mathrm{~cm}}^{1 \%}=$ 2592 for $\beta$-carotene, following the method (355 / IV) described in IAL (2008).

\section{Mass and income balance calculations}

The mass and yield balance for the process of obtaining mangaba vinegar accounted for the mass quantities of the raw material, alcohol obtained during fermentation, consumed sugar, and acetic acid in the final product (AQUARONE et al., 2001). The yield, efficiency, and productivity of the alcoholically fermented mangaba (FAM) were calculated according to equations 2, 3, and 4, respectively. Moreover, equations 5 and 6 were used to calculate the yield and productivity of Mangaba vinegar (VM), respectively.

$$
\begin{aligned}
& \text { FAM yield }(\%)=\frac{\text { produced ethanol }}{\text { sugar consumed }} \times 100 \\
& \text { FAM efficiency }(\%)=\frac{\text { produced ethanol }}{\text { theoretical ethanol }} \times 100 \\
& \text { FAM productivity }(g / L)=\frac{\text { alcoholic content }}{\text { fermentation time }} \\
& \text { VM yield }(\%)=\frac{\text { produced acetic acid }}{\text { consumed alcohol }} \times 100 \\
& \text { VM productivity }(g / \text { Lh })=\frac{\text { acetic acid content }}{\text { oxidation time }}
\end{aligned}
$$

\section{Sensory analysis}

This study was approved by the Research Ethics Committee 8055 under the number CAAE 04173718.7.0000.8055 (ANVISA, 2012).

The affective method used the hedonic scale test (unstructured), where the scale ran from 0 equaling "dislike very much" to 10 equaling "like very much." The user's intention to consume was also indicated. The attributes evaluated were color, aroma, flavor, and global appearance (DUTCOSKY, 2013). The analysis was carried out by a team of 128 untrained tasters, with ages varying between 18 
and 74 years; there were 87 females and 39 males, and two tasters did not declare their sex. Sensory evaluation of mangaba vinegar was carried out according to FERNANDES et al. (2019), where the tasters received the sample at a temperature of $25^{\circ} \mathrm{C}$ and was distributed in disposable cups containing $2 \mathrm{~mL}$ of the vinegar. Cups containing water were available to the tasters.

\section{Statistical analysis of the data}

The results obtained from the physicochemical analysis of the pulp and fermented mangaba were subjected to descriptive statistical analysis by mean and standard deviation. Principal component analysis allows for a grouping of variables in dimensions that represent a linear combination for the parameters of color, $\mathrm{pH}$, volatile acidity, and aroma, to identify correlations between them. The Shapiro-Wilk normality test was applied. When considered parametric, an analysis of variation (ANOVA) was performed, followed by the Tukey test. For nonparametric cases, the Kruskal-Wallis average test was applied, followed by the Nemenyi average comparison test between the raw pulp, alcoholically fermented pulp, and mangaba vinegar, which included the total phenolic compounds, total carotenoids, and color parameters $\mathrm{L}^{*}$ (brightness), $\mathrm{a}^{*}$ (red index), $\mathrm{b}^{*}$ (yellow index), $\mathrm{C}^{*}$ (chromaticity index), and $\mathrm{h}^{*}$ (hue angle).

For development of the principal component analysis (PCA), using data obtained from the production of vinegar in eight repetitions each in triplicate, and the sensory analysis, were applied as a criterion for determining the first two main components, eigenvalues greater than one $(>1)$ as suggested by Kaiser $(\lambda i>1)$ was used (KAISER, 1958; HONGYU et al., 2015). PCA was visualized using cluster analysis (FRALEY \& RAFTERY, 2002). The factors were determined using $\mathrm{R}$ 3.6.1 (R Development Core Team, 2016). The "psych," "FactoMineR," "vegan" packages were used for the application of PCA and the cluster model "cluster."

Pearson's coefficient was used to measure the correlation between the two variables. The range was assumed to be from -1 to 1 , which can be calculated by the cosine of the angle formed between the vectors, compared two by two. Thus, vectors with angles close to $0^{\circ}$ (zero degrees) indicate a strong positive correlation, vectors with angles close to $180^{\circ}$ (one hundred and eighty degrees) indicate a strong negative correlation, and vectors with angles close to $90^{\circ}$ (ninety degrees) indicate a weak or nonexistent correlation.

\section{RESULTS AND DISCUSSION}

\section{Physicochemical parameters:} Mangaba pulp

The physicochemical results for mangaba pulp determined in this study and reported in the literature are described in table 1. The "Ratio" value (soluble solids/total solids) found in the mangaba pulp was 10.0. According to PERFEITO et al. (2015), this value can indicate the maturation stage of an unripen fruit, and higher values were reported by other authors (CARNELOSSI et al., 2004; CARDOSO et al., 2014; NASCIMENTO et al., 2014; LIMA et al., 2015a; BRASIL et al., 2016). The importance of determining the "Ratio" is related to the composition of sugars and organic acids in fruits, which can directly affect the flavor and, consequently, its sensory characteristics (PAIVA et al., 2018).

In this work, the values of total and reducing sugars were $5.8 \%$ and $5.1 \% \quad(\mathrm{w} / \mathrm{w})$, respectively. In a fruit, low total sugar values, as in the fresh strawberry $(1.9 \%(\mathrm{w} / \mathrm{w}$, GUIMARÃES et al., 2014) and acerola (3.2\% (w/w, DANTAS et al., 2010), enable the production of vinegars (UBEDA et al., 2013; GOKIRMAKLI et al., 2019; PINO et al., 2019). The carbohydrate content in the raw material provides a potential energy source for yeasts during the alcoholic fermentation process. In addition, enzymes can be applied to generate more available glucose in the fermentation medium (COLLADOS et al., 2020).

The $\mathrm{pH}$ of the mangaba pulp was 5.0, and the total acidity was $0.8 \%$. Decreases in acidity and increases in $\mathrm{pH}$ correspond to a natural maturation process (CHITARRA \& CHITARRA, 2005; PERFEITO et al., 2015) and are consistent with values reported in that study. This $\mathrm{pH}$ value is suitable for promoting yeast activity during the alcoholic fermentation process. The optimal $\mathrm{pH}$ for yeast growth is between 4.5 and 6.0. In this interval, undesirable bacterial growth is avoided (ALVARENGA et al., 2017). In other reports, the total acidity of mangaba pulp in citric acid ranged from $0.7 \%$ to $1.7 \%$ and the pH from 3.2 to 3.9 (CARNELOSSI et al., 2004; CARDOSO et al., 2014; NASCIMENTO et al., 2014; LIMA et al., 2015b; PERFEITO et al., 2015).

\section{Alcoholic fermentation process}

In the alcoholic fermentation process, alcohol is generated from the sugars present in the starting raw material. During the fermentation process, the reducing sugar content decreased from $5.1 \%(\mathrm{w} / \mathrm{w})$ to $0.6 \%(\mathrm{w} / \mathrm{w})$ (Table 2$)$. Fermentation was determined 
Table 1 - Average values \pm standard deviation of the physicochemical parameters of the mangaba pulp.

\begin{tabular}{|c|c|c|c|c|c|c|c|c|c|c|c|}
\hline References & Brix & T.A (\%) & R.S (\%) & T.S (\%) & $\mathrm{pH}$ & "Ratio" & $\mathrm{P}(\%)$ & L (\%) & A (\%) & M (\%) & $\mathrm{aW}$ \\
\hline $\begin{array}{l}\text { In this study } \\
\text { Average } \pm \mathrm{SD}^{1}\end{array}$ & $8.0 \pm 0.0$ & $0.8 \pm 0.0$ & $5.1 \pm 0.2$ & $5.8 \pm 0.5$ & $5.0 \pm 0.0$ & $10.0 \pm 0.0$ & $1.6 \pm 0.1$ & $3.0 \pm 0.5$ & $0.3 \pm 0.0$ & $82.8 \pm 0.2$ & $0.98 \pm 0.0$ \\
\hline Legislation $^{2}$ & 8.0 & 0.7 & - & - & 2.8 & - & - & - & - & - & - \\
\hline $\begin{array}{l}\text { CARNELOSSI } \\
\text { et al., } 2004\end{array}$ & $15.2 \pm 1.0$ & $0.7 \pm 0.1$ & - & - & $3.5 \pm 0.1$ & 21.7 & - & - & - & - & $0.98 \pm 0.0$ \\
\hline $\begin{array}{l}\text { SILVA et al., } \\
2008\end{array}$ & - & - & - & $10.0 \pm 0.2$ & - & - & $1.2 \pm 0.0$ & $2.4 \pm 0.0$ & $0.6 \pm 0.0$ & $82.4 \pm 0.1$ & - \\
\hline $\begin{array}{l}\text { CARDOSO et } \\
\text { al., } 2014\end{array}$ & $15.1 \pm 1.1$ & $0.8 \pm 1.2$ & - & $2.3 \pm 0.2$ & $3.6 \pm 0.1$ & 18.9 & $0.8 \pm 0.1$ & $1.7 \pm 0.1$ & $0.6 \pm 0.1$ & $83.0 \pm 1.4$ & - \\
\hline $\begin{array}{l}\text { NASCIMENTO } \\
\text { et al., } 2014\end{array}$ & 15.8 & 0.7 & - & - & 3.9 & 18.5 & - & - & - & - & - \\
\hline $\begin{array}{l}\text { ASSUMPÇÃO } \\
\text { et al., } 2014\end{array}$ & - & - & - & $8.6 \pm 0.0$ & - & - & $0.9 \pm 0.0$ & $2.3 \pm 0.0$ & $0.4 \pm 0.0$ & $83.3 \pm 0.2$ & - \\
\hline $\begin{array}{l}\text { LIMA et al., } \\
\text { 2015b }\end{array}$ & $16.0 \pm 0.9$ & $1.0 \pm 0.04$ & - & $11.5 \pm 0.3$ & $3.2 \pm 0.0$ & 15.1 & $1.2 \pm 0.0$ & $2.3 \pm 0.0$ & $0.4 \pm 0.0$ & $82.4 \pm 0.2$ & - \\
\hline $\begin{array}{l}\text { PERFEITO et } \\
\text { al., } 2015\end{array}$ & $15.7 \pm 0.0$ & $1.7 \pm 0.0$ & - & - & $3.8 \pm 0.1$ & 14.8 & - & - & - & - & - \\
\hline $\begin{array}{l}\text { SIQUEIRA et } \\
\text { al., } 2018\end{array}$ & 19.0 & 0.9 & - & - & - & - & - & - & - & - & - \\
\hline
\end{tabular}

${ }^{1}$ S.D: Standard deviation; ${ }^{2}$ Legislation, BRAZIL, 2009b. ${ }^{\circ}$ Brix: Soluble solids in ${ }^{\circ}$ Brix, a $20{ }^{\circ} \mathrm{C}$; T.A: Total Acidity in Citric Acid (\%); R.S Reduced Sugar (\%); T.S: Total Sugar (\%); "Ratio": soluble solids ratio / Total Acidity; P: Protein (\%); L: Lipid (\%); A: Ashes (\%); M: Moisture (\%); aW: Water activity.

to be complete by the stabilization of the alcohol content at $5.2 \%(\mathrm{v} / \mathrm{v})$. This is within the $4 \%$ to $14 \%$ $(\mathrm{v} / \mathrm{v})$, at $20{ }^{\circ} \mathrm{C}$ range for fruit alcoholic fermentation allowable under Brazilian law (BRASIL, 2012b).

The alcohol content of fermented fruit is reported to be between $3.5 \%$ and $9.5 \%$ for several fruits, such as jabuticaba, orange, and kiwi (ILHA et al., 2000; BORTOLINI et al., 2001; TESSARO et al., 2010; ARAÚJO et al., 2012; CUNHA et al., 2016; DIAS et al., 2016). This wide difference may be related to the total sugar content, what nutrients and energy sources are available for the consumption by the yeast, and the specific fermentation conditions. It is noteworthy that concentrations above $8 \%(\mathrm{v} / \mathrm{v})$ of ethanol can denature yeasts, which are often reused in further fermentation cycles (SOUZA \& MONTEIRO, 2011). Pectin, present in fruits, is a non-starchy component that can be converted into fermentable sugars through enzymatic activity and is a substrate for yeasts (TUNGLAND \& MAYER, 2002).

The beverage industry has developed methods to incorporate enzymes during preparation. The most commonly used enzymes are pectinase, cellulase, amylase, hemicellulase, glycosidase, and glucanase. The enzymatic activity contributes to different aspects of the final product, improves the quality of aroma release, color development, and increases yields. Enzymes are used both in the phase

Table 2 - Average values \pm standard deviation of the alcoholically fermented mangaba control analyzed after seven days in the bioreactor.

\begin{tabular}{lc}
\hline Parameters & Alcoholic fermented mangaba \\
\hline Alcohol content $\left(\% \mathrm{v} / \mathrm{v}\right.$ at $\left.20^{\circ} \mathrm{C}\right)$ & $5.2 \pm 0.0$ \\
Soluble solids ${ }^{\circ}$ Brix, at $20{ }^{\circ} \mathrm{C}$ & $8.3 \pm 0.0$ \\
Total sugar $\%(\mathrm{w} / \mathrm{w})$ & $0.6 \pm 0.0$ \\
Reduced dry extract $(\mathrm{g} / \mathrm{L})$ & $43.0 \pm 1.7$ \\
$\mathrm{pH}$ & $3.5 \pm 0.0$ \\
\hline
\end{tabular}


before the fermentation and in the aging of wines (UZUNER \& CEKMECELIOGLU, 2019; SIEIRO et al., 2012; MOJSOV et al., 2015). Enzymatic hydrolysis used to prepare the banana for alcoholic fermentation increased the availability of fermentable sugars, resulting in higher ethanol yields (SOUZA et al., 2009). In this study, we next determined if the alcoholic yield obtained is related to the addition of a mixture of the enzymes cellulase, hemicellulase, and pectinase.

Although the decline in SST is generally associated with sugar content for monitoring during fermentation (TESSARO et al., 2010; ARAÚJO et al., 2012; DIAS et al., 2016; LEONÉS et al., 2019), in this study, ${ }^{\circ}$ Brix showed low sensitivity, as there was no significant difference between the raw (8.0) and fermented pup (8.3). The fermented mangaba pulp had a $\mathrm{pH}$ value of 3.5 (Table 2). SOUZA \& MONTEIRO (2011) established that a variation between 3.0 to 4.0 does not require correction because acetic acid bacteria can tolerate $\mathrm{pH}$ up to 6.3 (SENGUN et al., 2011; MAS et al., 2014; DIAS et al., 2016; GOMES et al., 2018).

\section{Mangaba vinegar}

In comparing with the Brazilian legislation for fruit vinegars, the values of the parameters in the mangaba vinegar obtained fully meet all legal requirements (Table 3) (BRASIL, 2012a). The mangaba vinegar had a volatile acidity of $4.4 \%$ $(w / v)$. Some variation has been observed, such as by GIUFFRÈ et al. (2019) who found volatile acidity values of $2.9 \%(\mathrm{w} / \mathrm{v})$ for bergamot vinegar (ARAÚJO et al., 2012), 4.3\% (w/v) for orange vinegar, (CUNHA et al., 2016), $4.7 \%(\mathrm{w} / \mathrm{v})$ for blackberry vinegar, (PINO et al., 2019), 4.9\% (w/v) for acerola vinegar (RODA et al., 2017), 5.0\% for pineapple vinegar (w/v) and (SPINOSA et al., 2015), 7.1\% (w/v) for rice vinegar. Despite the variability in many quality parameters related to vinegars, acidity-level regulations are established in national and international parameters (FDA, 1980; OZTURK et al., 2015). These variations may be related to factors such as the fruit used, their monosaccharide levels, alcoholic strength in the fermentation, and the acetic acid bacteria used (CUNHA et al., 2016; XIA et al., 2016). The final mangaba vinegar had a $\mathrm{pH}$ of 3.1 (Table 3 ). The $\mathrm{pH}$ of vinegars produced from fruits and cereals such as alcohol vinegars had a $\mathrm{pH}$ of 2.9, jabuticaba had a $\mathrm{pH}$ of 2.7, and pineapple had a $\mathrm{pH}$ of 3.0 (DIAS et al., 2016; RODA et al., 2017; MACHADO et al., 2019). Sensory characteristics are mainly influenced by acidity and $\mathrm{pH}$ in the raw materials used in the preparation of fermented acetic acid when the final $\mathrm{pH}$ value varies from 2.4 to 3.2 , the acidity will be approximately 5\% (w/v) (MARQUES et al., 2010).

The reduced dry extract content of mangaba vinegar was $44.3 \mathrm{~g} / \mathrm{L}$ and $3.0 \mathrm{~g} / \mathrm{L}$ for ash. This parameter represents the resulting content (minerals and organic material) of water evaporation and volatile substances (MARQUES et al., 2010). In a study on quality control of commercial acetic acid fermentation, MARQUES et al. (2010) observed higher levels of reduced dry extract of $48.8 \mathrm{~g} / \mathrm{L}, 38.3$ $\mathrm{g} / \mathrm{L}$, and $23.4 \mathrm{~g} / \mathrm{L}$ for orange vinegar with honey, orange and tangerine vinegar and corn vinegar. In this study, the results observed may be related to the filtration method, as there are different filtration processes in the vinegar industry used to clarify the product but can change the concentration and the

Table 3 - Average values \pm standard deviation of the physicochemical parameters of mangaba vinegar.

\begin{tabular}{|c|c|c|c|}
\hline \multirow[t]{2}{*}{ Parameters } & \multirow[t]{2}{*}{ Mangaba vinegar } & \multicolumn{2}{|c|}{ 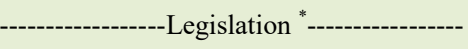 } \\
\hline & & Minimum & Maximum \\
\hline Alcohol content $\left(\% \mathrm{v} / \mathrm{v}\right.$ at $\left.20^{\circ} \mathrm{C}\right)$ & $<\mathrm{L} . \mathrm{Q}^{* *}$ & - & 1 \\
\hline Volatile acidity in acetic acid \% (w/v) & $4.4 \pm 0.1$ & 4 & - \\
\hline Reduced dry extract $(\mathrm{g} / \mathrm{L})$ & $44.3 \pm 1.5$ & 6 & - \\
\hline Ashes $(\mathrm{g} / \mathrm{L})$ & $3.0 \pm 0.4$ & 1 & 5 \\
\hline Sulfates (g/L of potassium sulfate) & $<$ L.Q. ${ }^{* *}$ & & 1 \\
\hline $\mathrm{pH}$ & $3.1 \pm 0.0$ & - & - \\
\hline \multirow{3}{*}{ Organoleptics } & \multicolumn{3}{|c|}{${ }^{*}$ Smell: characteristic } \\
\hline & \multicolumn{3}{|c|}{$\begin{array}{l}\text { *Color: according to the raw material that gave rise to the } \\
\text { composition }\end{array}$} \\
\hline & \multicolumn{3}{|c|}{ *Aspect: absence of elements foreign to its nature and composition } \\
\hline
\end{tabular}

*Legislation BRAZIL (2012a), art. 6 , and Annex III. < L.Q. ${ }^{* *}$ is below the limit of quantification.

Ciência Rural, v.51, n.10, 2021. 
mineral content (LEONEL et al., 2015; OZTURK et al., 2015). Mangaba fruit is a potential source of minerals such as calcium, zinc, phosphorus, and iron (NARAIN et al., 2018; BRAMONT et al., 2018).

As expected, a decrease in alcohol content is observed due to the increase in acidity, as the bacteria oxidize the available alcohol to acetic acid (OZEN et al., 2019). The alcohol content in mangaba vinegar was below the detection limit $(0.0 \mathrm{mg}$ of ethanol) of the analytical technique used.

Color parameters and phenolic and total carotenoid compounds for pulp, alcoholic fermentation, and vinegar

The mangaba fruit contains phenolic compounds such as rutin and quercetin (NARAIN et al., 2018), which can provide yellow pigmentation in fruits and vegetables (CHEN et al., 2010; KAWARYGIELSKA et al., 2018). The total phenol content of the mangaba raw pulp, fermented pulp, and vinegar were $38.9 \mathrm{mg} / 100 \mathrm{~g}, 13.5 \mathrm{mg} / 100 \mathrm{~g}$, and $19.2 \mathrm{mg} / 100 \mathrm{~g}$, respectively. The angle hues were $79.0^{\circ}, 87.3^{\circ}$, and $78.0^{\circ}$, respectively, and the yellow index was 13.3, 8.0, and 9.2, respectively (Table 4). From our results, we can observe a decrease between the parameters of tonality index (fermented pulp and vinegar), yellow index, and phenolic compounds (pulp and vinegar), which may be related to degradation of those compounds. However, despite the significant difference $(\mathrm{P}<0.05)$ in the analysis of total phenolic compounds between the pulp and the other products, we emphasize that raw pulp of mangaba was used for this analysis, while the analysis of the fermented pulp and vinegar was performed on the respective filtered final products. This may explain the significant reduction in the total content of phenolic compounds, suggesting losses during the filtering process because the fermented pulp and vinegar showed no significant difference.

During the alcoholic fermentation process, the alcohol generated can influence the degradation of phenolic compounds, resulting in colorless substances and a consequential loss of pigmentation (JACKSON, 2008). The presence of oxygen in vinegars can result in chemical and enzymatic reactions, such as alteration of phenolic compounds and loss of aroma and color (MAS et al. (2014). Additionally, factors such as the raw material, production, and storage may influence these characteristics as well. (CASALE et al., 2006; XU et al., 2007; GANDA-PUTRA et al., 2019) In addition to acting as antioxidants, phenolic compounds are responsible for the color and astringency of vinegars. In a study by HORNEDO-ORTEGA et al. (2017), it was observed that oxidation changed the color of alcoholically fermented strawberry, which was directly correlated to the decrease in anthocyanins.

The total carotenoid content of the mangaba raw pulp, fermented pulp, and vinegar were $2.7 \mathrm{mg} / 100 \mathrm{~g}, 2.3 \mathrm{mg} / 100 \mathrm{~g}$, and $2.6 \mathrm{mg} / 100 \mathrm{~g}$, respectively. Related studies on the quantification of total carotenoids in mangaba pulp have been reported to be $0.7 \mathrm{mg} / 100 \mathrm{~g}$ (LIMA et al., 2015a), $0.3 \mathrm{mg} / 100 \mathrm{~g}$ (RUFINO et al., 2010), and $0.1 \mathrm{mg} / 100 \mathrm{~g}$ (CARDOSO et al, 2014). Those values are lower than what we observe for mangaba pulp here. In addition, the $\mathrm{h}^{*}$ and $\mathrm{b}^{*}$ indexes trend towards yellow, thus demonstrating the hue of the final product, which is characteristic of the color of the mangaba fruit. According to VIEIRA et al. (2017) and REIS et al. (2019), the

Table 4 - Color parameters, phenolic compound content, and total carotenoid content for the raw pulp, alcoholically fermented mangaba, and mangaba vinegar.

\begin{tabular}{|c|c|c|c|}
\hline Parameters & Mangaba Pulp & Alcoholic fermented mangaba & Mangaba vinegar \\
\hline Total phenolic compounds (mg/100 g) & $38.9 \pm 0.2^{\mathrm{a}}$ & $13.5 \pm 1.0^{\mathrm{b}}$ & $19.2 \pm 8.2^{\mathrm{b}}$ \\
\hline Total carotenoids $(\mathrm{mg} / 100 \mathrm{~g})$ & $2.7 \pm 0.4^{\mathrm{a}}$ & $2.3 \pm 0.3^{\mathrm{b}}$ & $2.6 \pm 0.6^{\mathrm{ab}}$ \\
\hline & -------Color--- & -------------------------- & -------------------- \\
\hline $\mathrm{L}^{*}$ & $49.6 \pm 1.1^{\mathrm{a}}$ & $49.4 \pm 0.3^{\mathrm{a}}$ & $47.0 \pm 1.1^{\mathrm{b}}$ \\
\hline$a^{*}$ & $2.6 \pm 0.1^{\mathrm{a}}$ & $0.4 \pm 0.0^{\mathrm{b}}$ & $2.0 \pm 0.5^{\mathrm{a}}$ \\
\hline$b^{*}$ & $13.3 \pm 0.8^{\mathrm{a}}$ & $8.0 \pm 0.2^{\mathrm{c}}$ & $9.2 \pm 0.5^{\mathrm{b}}$ \\
\hline $\mathrm{C}^{*}$ & $13.6 \pm 0.5^{\mathrm{a}}$ & $8.1 \pm 0.1^{\mathrm{c}}$ & $9.5 \pm 0.4^{b}$ \\
\hline $\mathrm{h}^{*}$ & $79.0 \pm 0.1^{\mathrm{b}}$ & $87.3 \pm 0.3^{\mathrm{a}}$ & $78.0 \pm 3.7^{\mathrm{b}}$ \\
\hline
\end{tabular}

Averages followed by the same lower-case letters on the same line do not differ statistically from each other by the Nemenyi test ( $\mathrm{P}>$ 0.05 ). ( ${ }^{*}$ luminosity; $a^{*}$ red index; $b$ * yellow index; $C^{*}$ chromaticity index; ${ }^{*}$ angle hue). 
exocarp of mangaba has yellow or green tones, and the pulp is yellow, (LIMA et al., 2015b), which suggests that the ripen fruits tend towards yellowish tones. Carotenoids from fruits and vegetables, such as $\alpha$ - and $\beta$-carotene, give a yellow-orange pigmentation (AMORIM-CARRILHO et al., 2014). Total phenolic compounds and total carotenoids in vinegar of oranges remained constant during the aging period (DAVIES et al., 2017). According to RODRIGUEZ-AMAYA (2004), it is a challenge to keep these compounds present after fruit processing due to thermal activity, cutting, peeling, packaging, oxidative processes, and storage of the final product. As there was no change in the carotenoids between the pulp and the mangaba vinegar, the final product remains a source of these compounds.

\section{Principal component analysis (PCA) of mangaba vinegar}

Principal component analysis (PCA) was applied to identify possible correlations between the following mangaba vinegar physicochemical variables: $\mathrm{a}\left(\mathrm{a}^{*}\right.$, red index $), \mathrm{b}\left(\mathrm{b}^{*}\right.$, yellow index $), \mathrm{C}\left(\mathrm{C}^{*}\right.$, chromaticity index), L ( $\mathrm{L}^{*}$, luminosity), $\mathrm{h}$ ( $\mathrm{h}^{*}$, angle hue), A_V (volatile acidity in acetic acid), A (ashes) C_P (total phenolic compounds), and E_S_R (reduced dry extract). The eigenvalues and eigenvectors are calculated based on the correlation matrix. Following the Kaiser criteria, we obtain $\lambda 1=6.1$ and $\lambda 2=1.3$, which represent component 1 and component 2 , respectively, with a percentage of $61.0 \%$ for dimension 1 and $12.9 \%$ for dimension 2 (Figure 2). This accounts for $70.1 \%$ of the total variation in the two components.

The dimensions (DM1 and DM2) were generated by the eigenvectors that represent the weight of each variable. When there is a large eigenvector in the first component, there is possibly a smaller eigenvector in the second component, thus indicating which component accounts for that variable (LIPS \& DUIVENVOORDEN, 1996; LIMA et al., 2018). Therefore, by analyzing the eigenvectors, we can identify the contributions of each component, which can be seen in equations (7) and (8).

$$
\mathrm{DM} 1=-0.70 \mathrm{pH}+0.91 \mathrm{~L}-0.94 \mathrm{a}+0.85 \mathrm{~b}+
$$
$0.75 \mathrm{C}+0.96 \mathrm{~h}+0.39$ extract_s_reduced -0.65 volatile acidity +0.53 ashes +0.87 with $\_$phenolic.

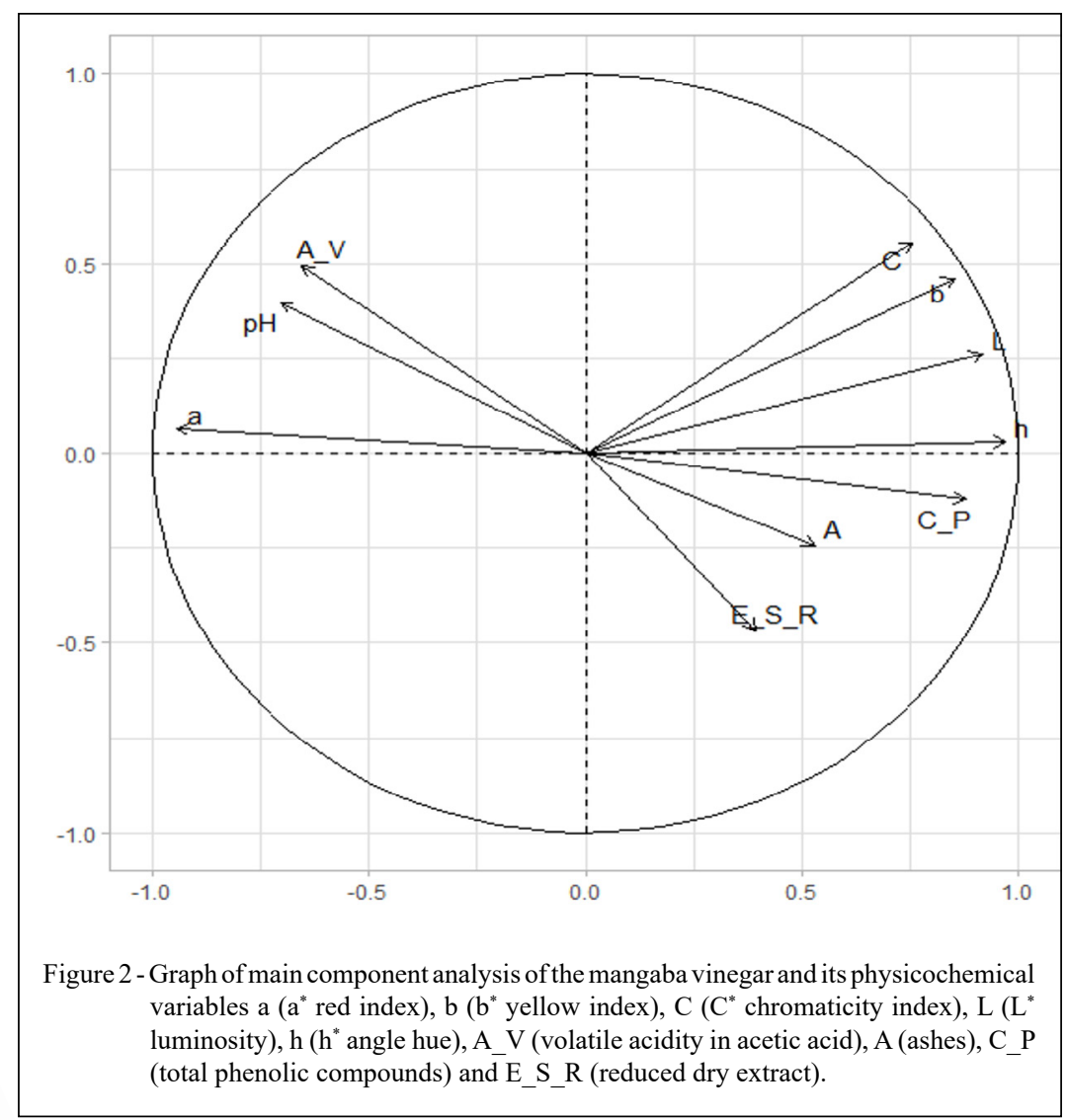

Ciência Rural, v.51, n.10, 2021. 
$\mathrm{DM} 2=0.39 \mathrm{pH}+0.26 \mathrm{~L}+0.06 \mathrm{a}+0.46 \mathrm{~b}$

$+0.55 \mathrm{C}+0,03 \mathrm{~h}-0.46$ extract_s_reduced +0.49 volatile_acidity -0.24 ashes +0.12 with $\_$phenolic.

The variables $\mathrm{pH}$, volatile acidity, ash, and reduced dry extract have a strong negative correlation. This was also observed by RAMÍREZ et al. (2017) and LEAL et al. (2013). Possibly, the decrease in the content of total solids influences the ionic balance of the water, thus changing the acidity. The increase in acidity may be related to substances such as pectin, which is a branched compound composed of a mixture of acidic and neutral polymers derived from methyl D-galacturonate, which constitutes part of the dry mass of the vegetable cell wall and is frequently present in fruits (RUIZ \& TAPIA, 2019). It should be noted that D-galacturonic acid is the main constituent of a complex group of polysaccharides that make up pectin and has high solubility in water (DHINGRA et al., 2012).

The variables of phenolic compounds and $\mathrm{a}^{*}$ (red index) have a strong negative correlation. It can be assumed that this is attributed to the variable $\mathrm{a}^{*}$, which tends to indicate red color (RAMOS \& GOMIDE, 2007). Since the mangaba fruit used has phenolic compounds that give it a yellow pigment color (CHEN et al., 2010; NARAIN et al., 2018; KAWA-RYGIELSKA et al., 2018), the negative correlation between these compounds and the color red make sense. Also observed are the influence of color parameters $b^{*}$ (yellow index), $\mathrm{C}^{*}$ (chromaticity index), and $\mathrm{h}^{*}$ (angle hue) in mangaba vinegar. According to SUN (2020), the raw material and the type of fermentation contribute to the presence of vitamins, phenolic compounds, or other bioactive molecules.

The $\mathrm{pH}$ and volatile acidity variables in acetic acid presented a positive correlation, which may be related to the presence of weak organic acids resulting from alcohol oxidation carried out by the acetic acid bacteria (OZEN et al., 2019). The mineral salts present in fruits may also contribute, which could help explain the observed buffering effect, demonstrating the small $\mathrm{pH}$ variations considering the increase in acidity (GONÇALVES et al., 2006).

The angle hue $\left(\mathrm{h}^{*}\right)$ and phenol content have a strong positive correlation, and the greatest influence is represented by the $h^{*}$ parameter. According to RUFINO et al. (2010), mangaba fruits contain compounds such as yellow flavonoids and, according to CHAVES NETO et al. (2018), these components in vegetables are related to pigmentation and protection against incident ultraviolet rays, which may contribute to the color of the final product observed as the angle hue $\left(h^{*}\right)$. We observed phenolic compounds present in the mangaba vinegar. KADIROGLU (2018) reported that the levels of phenolic compounds in vinegars were highly correlated with antioxidant activity.

The ashes and reduced dry extract variables show a strong positive correlation in the product. The ashes represent the mineral elements present in the vinegar (RIZZON \& MIELE, 2002), which originate in the fruit used in the fermentation process, while the amount of reduced dry extract determines the fermented, mineral, and organic composition (AQUARONE et al., 2001; MARQUES et al., 2010). The results from mangaba pulp ashes were $3.0 \mathrm{~g} / \mathrm{L}$ and from the vinegar $3.0 \mathrm{~g} / \mathrm{L}$, and for the value of the reduced dry extract in the fermented pulp was $43.0 \mathrm{~g} / \mathrm{L}$ and $44.3 \mathrm{~g} / \mathrm{L}$ in the vinegar remained. These results suggest that the processing to obtain mangaba vinegar was adequate.

PCA analysis has been applied to investigations of the composition of volatile compounds in vinegars produced from red wine and apples (CALLEJÓN et al., 2009; LIU et al., 2019). It has also been applied to the correlation between grape variety or geographical location in fine wines (OLIVEIRA et al., 2011), for characterizing the mineral content of wine vinegars (GUERRERO et al., 1997), and for analyzing the chemical composition and antioxidant characteristics of traditional and industrial Zhenjiang vinegar during the aging process (ZHAO et al., 2018).

\section{Mass balance and yields of alcoholic fermentation and acetic oxidation}

The mass balance and yields for the alcoholically fermented mangaba were calculated based on $225.0 \mathrm{~g}$ of sugar consumed, which produced 110.8 $\mathrm{g} / \mathrm{L}$ of ethanol. Based upon the theoretical yield for ethanol of $114.7 \mathrm{~g} / \mathrm{L}$ theoretical alcohol content of $41.0 \mathrm{~g} / \mathrm{L}$, and fermentation time of $96 \mathrm{~h}$, this process resulted in of $49.2 \%$ yield, $96.5 \%$ efficiency and 0.4 $\mathrm{g} / \mathrm{L} \cdot \mathrm{h}$ productivity.

Studies on the production of fruit wines found lower values for productivity, such as $0.3 \mathrm{~g} / \mathrm{L} \cdot \mathrm{h}$ for cagaita wine (OLIVEIRA et al., 2011), $0.05 \mathrm{~g} / \mathrm{L} \cdot \mathrm{h}$ for cacao, gabiroba, jabuticaba, and umbu wines, 0.03 $\mathrm{g} / \mathrm{L} \cdot \mathrm{h}$ for cupuaçu wine (DUARTE et al., 2010), 0.09 $\mathrm{g} / \mathrm{L} \cdot \mathrm{h}$ for sour cherry wine (OZEN et al., 2019), and $0.10 \mathrm{~g} / \mathrm{L} \cdot \mathrm{h}$ for bergamot wine. Productivity is a critical indicator of industrial economic potential, mainly related to technological processes and organizational development (RATTNER, 1967).

The mangaba vinegar consumed $132.03 \mathrm{~g}$ of alcohol and produced $118.8 \mathrm{~g}$ of acetic acid with a concentration of $44.0 \mathrm{~g} / \mathrm{L}$ in $72 \mathrm{~h}$ oxidation time. Thus, the yield was $90.0 \%$ with a productivity of $0.6 \mathrm{~g} / \mathrm{L} \cdot \mathrm{h}$. 
In studies on the generation of fruit vinegars, cherry vinegar had a productively of $0.04 \mathrm{~g} / \mathrm{L} \cdot \mathrm{h}$ and $95 \%$ yield (KAWA-RYGIELSKA et al., 2018), blackberry vinegar had $0.2 \mathrm{~g} / \mathrm{L} \cdot \mathrm{h}$ productive and $27 \%$ efficiency, raspberry vinegar had $0.3 \mathrm{~g} / \mathrm{L} \cdot \mathrm{h}$ productivity and $30 \%$ efficiency (BOONSUPA, 2018), jaboticaba vinegar had $0.3 \mathrm{~g} / \mathrm{L} \cdot \mathrm{h}$ productivity and $79 \%$ efficiency (DIAS et al., 2016), pineapple vinegar had $0.07 \mathrm{~g} / \mathrm{L} \cdot \mathrm{h}$ productivity and $62 \%$ efficiency (RODA et al. 2017), and mango vinegar had $0.4 \mathrm{~g} / \mathrm{L} \cdot \mathrm{h}$ productivity and $52 \%$ efficiency (COELHO et al. 2017). The conversion of $1 \mathrm{~g}$ of ethanol into $1 \mathrm{~g}$ of acetic acid $(76.69 \% \mathrm{w} / \mathrm{w})$ is considered as the minimum threshold to classify the vinegar process as one of industrial interest. The achieved value of $90 \%$ for mangaba vinegar indicates the possibility of applying the process for making this vinegar on larger scales (ILHA et al., 2000). According to COELHO et al. (2017), one of the factors that can directly affect yield and productivity are long acetification methods that lead to ethanol losses.

\section{Principal component analysis (PCA) of mangaba vinegar sensory characteristics}

The results of the sensory analysis of mangaba vinegar were evaluated by PCA, where a correlation matrix was developed assessing the color, aroma, flavor, overall appearance, and consumption intent. As such, we can analyze the correlation between the variables and the calculation of eigenvalues and eigenvectors. In this case, $\lambda 1=3.4626$ and $\lambda 2=0.5799$, which represent $69.47 \%$ for dimension 1 and $11.31 \%$ for dimension 2 respectively (Figure 3). Dimension formations can generated by equations (9) and (10). Subsequently, a graph of the variables is constructed, which allows interpretation between them.

$\mathrm{DM} 1=0.83$ color +0.78 aroma +0.87 flavor +0.91 global_appearance +0.74 consuption_intention $\mathrm{DM} 2=-0.22$ color -0.36 aroma +0.07 flavor - 0.06 global_appearance +0.62 consuption_intention For the attributes observed in the sensory analysis of mangaba vinegar, the parameters global appearance and color, and global appearance and flavor, showed a strong positive correlation. According to LAWLESS \& HEYMANN (1999) and TEIXEIRA (2009), these attributes are one of the main indicators initially noticed by consumers that are associated with reactions such as acceptance, indifference, or rejection. Consistent with the $\mathrm{h}^{*}$ index value of 78.0 and $C^{*}$ value of 9.5 indicating a yellow product with low intensity (RAMOS \& GOMIDE,

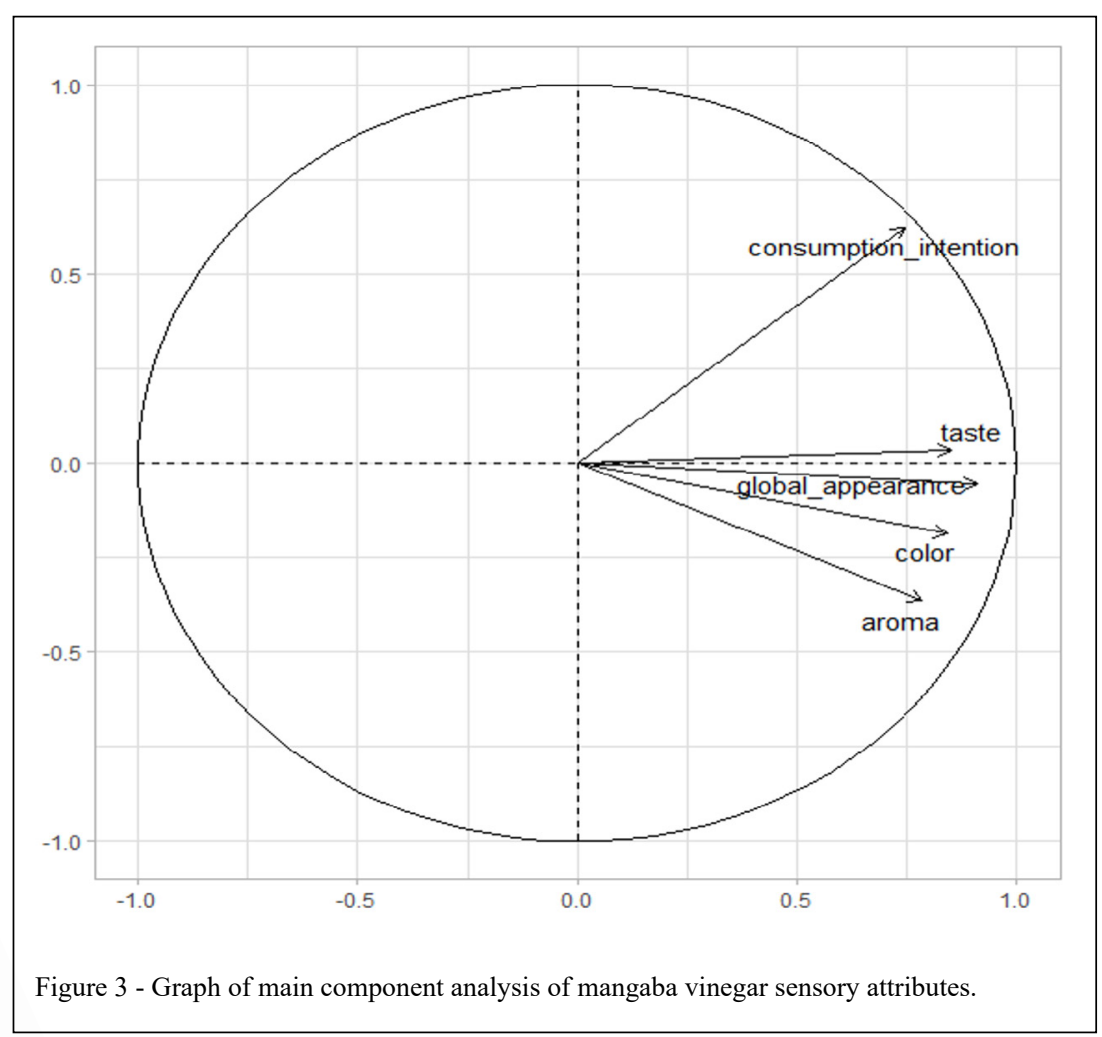

Ciência Rural, v.51, n.10, 2021. 
2007), it is expected that the global appearance was appealing to untrained tasters, as the appearance of mangaba vinegar is different from the most common commercial vinegars. The taste of the vinegar can be attributed to the consumer since, according to a study on orange vinegar by CEJUDO-BASTANTE et al. (2016), the type of raw material influences the taste results of sensory analysis. We also observed that the visual identity of mangaba vinegar was similar to that of the pulp used.

A positive correlation between global appearance and aroma was observed. This was observed by TESFAYE et al. (2002) in their study on sherry vinegar, and they indicate that this correlation is to the intensity and quality of the components. As seen in figure 3, in general, all attributes have a strong influence on vinegar, which may be related to the vinegar acidity due to acetic acid, which plays an important role in the sensory characteristics. Volatile carboxylic acids such as acetic acid have distinct desirable odors, expand the diversity of flavor and aroma, and have physicochemical stability and sanity of the beverage (RIZZON \& MIELE, 2002; JACKSON, 2008).

The cluster map (Figure 4) organizes the tasters as a function of the sensory attributes through overlap with the vectors that characterize them, 0 (zero) represents the average (7.0) of the attributes. The tasters in region $\mathrm{B}$ show a preference for the flavor attributes and would possibly intend to buy mangaba vinegar, while in region $(\mathrm{C})$, the tasters preferred global attributes of appearance, color, and aroma. In regions (A) and (D); however, some tasters gave lower marks and had lower ratings closer to 7 (seven) on the unstructured hedonic scale. According to TESFAYE et al. (2010), considering that vinegar is a condiment where acetic acid stands out, olfactory and gustatory evaluation becomes difficult for untrained tasters to identify other compounds, thus obscuring the origin of the raw material. Thus, other complementary sensory tests can be applied such as trained panel and temporal methods (SILVA et al., 2018) and projective methods (GAMBARO, 2018). Even though there is no consensus on how to conduct a sensory analysis of vinegar (ARAÚJO et al., 2012; UBEDA et al., 2016; CEJUDO-BASTANTE et al., 2016; TURHAN \& CANBAS, 2016; FERNANDES et al., 2019), only two tasters (41 and 13) were very upset and certain they would not consume the product. Therefore, with the results obtained, we can conclude that mangaba vinegar would have a good acceptance by consumers in general.

\section{CONCLUSION}

This study shows that it is possible to produce vinegar from the pulp of mangaba, a fruit from the Brazilian Cerrado, through semi-solid fermentation using an enzyme mixture (pectinase, cellulase, and hemicellulose) simultaneously during fermentation. The physicochemical qualities of this vinegar comply with current legislative requirements.

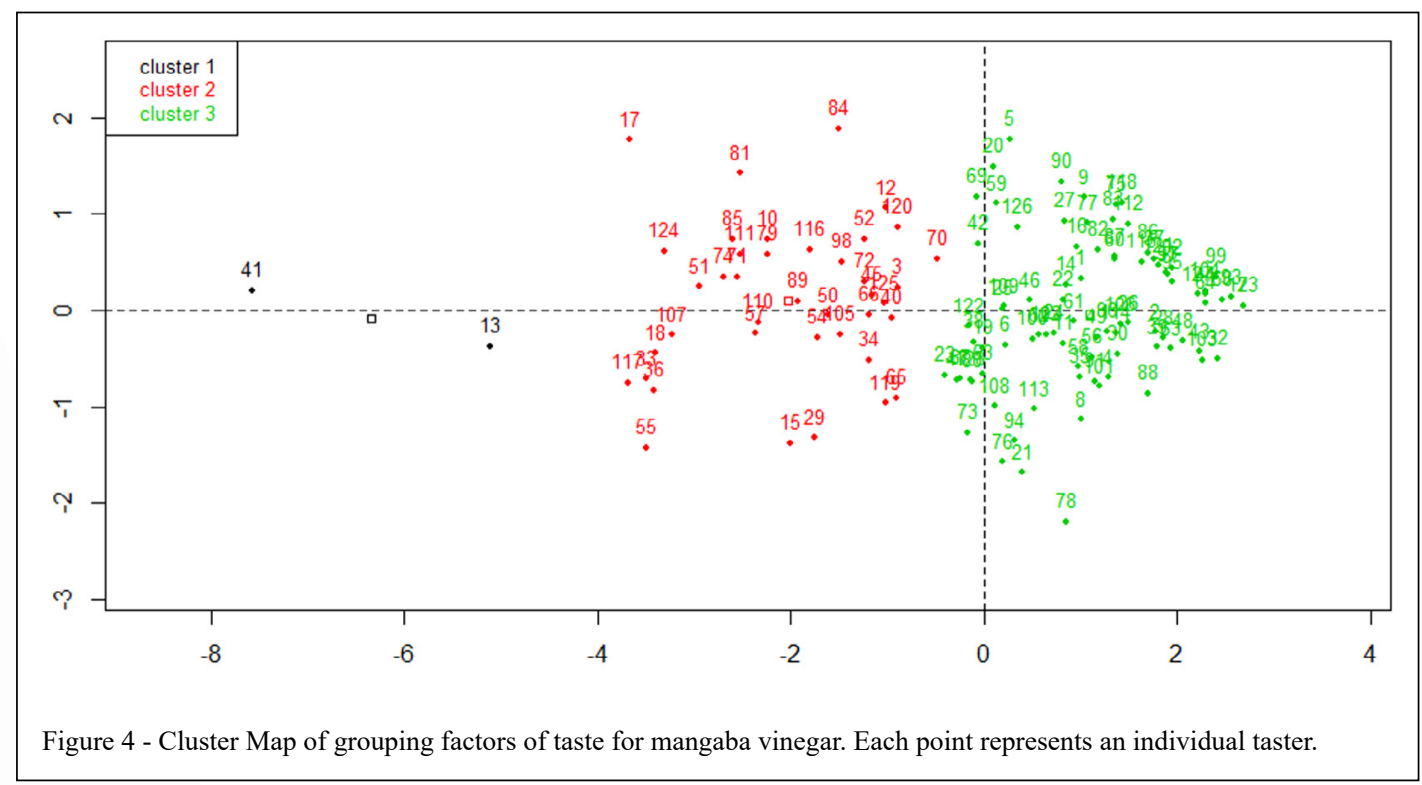

Ciência Rural, v.51, n.10, 2021. 
The final product contained bioactive compounds, namely phenolic compounds and carotenoids. In terms of the color parameters, according to the hue angle $\left(h^{*}\right)$, it can be affirmed that color from the raw material was maintained through the vinegarmaking process. A high yield was obtained both in alcoholic content and in acetic acid oxidation, which may be related to the contribution of enzymes used in the fermentation process and optimal conditions for the conversion of ethanol to acetic acid during the production of vinegar. In the sensory evaluation, principal component analysis was used to identify correlations between the parameters analyzed by the tasters. The taste, overall appearance, color, and aroma showed a strong positive correlation, and all attributes were above the average $(>7)$ of most tasters, indicating that the mangaba may have value for the development of a new product.

\section{ACKNOWLEDGMENTS}

We thank the Coordenação de Aperfeiçoamento de Pessoal de Nível Superior (CAPES) and the Fundação de Amparo a Pesquisa do Estado de Mato Grosso (FAPEMAT) for the scholarship (40709.580.28537.22082018-1582) grants and the Federal Institute of Education, Science and Technology of Mato Grosso for the publication of Public Notice IFMT/PROPES edition 04/2018 and Public Notice IFMT/PROPES 29/2018.

\section{DECLARATION OF CONFLICT OF} INTEREST

The authors declare no conflict of interest. The founding sponsors had no role in the design of the study; in the collection, analyses, or interpretation of data; in the writing of the manuscript, and in the decision to publish the results.

\section{AUTHORS' CONTRIBUTIONS}

All authors contributed equally to the design and writing of the manuscript. All authors critically reviewed the manuscript and approved the final version.

\section{REFERENCES}

ABNT. Associação Brasileira de Normas Técnicas. 1997. NBR 13920:1997. Sugar cane spirit - Determination of ethyl alcohol - Method of test. Available from: $<$ https://www.abntcolecao.com. br/normavw.aspx?ID=3280>. Accessed: May, 20, 2019.

ALVARENGA, M. V. et al. Análise microbiológica de polpas de frutas congeladas e industrializadas. Revista Científica da Faminas, v.12, n.3, p.60-65, 2017. Available from: <http:// periodicos.faminas.edu.br/index.php/RCFaminas/article/ view/392/350>. Accessed: Jun. 01, 2020

AMORIM-CARRILHO, K. T. Review of methods for analysis of carotenoids. Trend in Analytical Chemistry, v.56, p.49-73, 2014.
Available from: <https://doi.org/10.1016/j.trac.2013.12.011>. Accessed: Jun. 07, 2020. doi: 10.1016/j.trac.2013.12.011.

ANVISA. Agência Nacional de Vigilância Sanitária, 2012. Resolução no 466, de 12 de dezembro de 2012. Available from: <https://bvsms.saude.gov.br/bvs/saudelegis/cns/2013/ res0466 1212 2012.html>. Accessed: Jun. 26, 2020.

AOAC. Association of official analytical chemists. Official methods of analysis - AOAC International. 19th ed. Maryland, USA, 2012.

AQUARONE, E. et al. Biotecnologia industrial: Biotecnologia na produção de alimentos. In: Vinagres; Palma, M. S. A.; Carvalho, L. F. C. P.; Gavóglio, L. C. v. 4. $1^{\mathrm{a}}$ ed., São Paulo: Editora Edgard Blucher LTDA, p.183-208, 2001.

ARAÚJO, L. T. et al. Production of 'Lime' orange vinegar in the crafty module. Scienta Plena, v.8, n.12, p.1-7, 2012. Available from: $\quad<$ https://www.scientiaplena.org.br/sp/article/view/1077>. Accessed: Jun. 01, 2020.

ASSUMPÇÃO, C. F. et al. Characterization, antioxidant potential and cytotoxic study of mangaba fruits. Ciência Rural, v.44, n.7, p.1297-1303, 2014. Available from: <https://doi.org/10.1590/01038478 cr20130855>. Accessed: Jan. 25, 2020. doi: 10.1590/0103$8478 \mathrm{cr} 20130855$.

BOONSUPA, W. Chemical properties, antioxidant activities and sensory evaluation of berry vinegar. Revista Walailak de Ciência e Tecnologia, v.16, n.11, p.887-896, 2018. Available from: $<$ http://wjst. wu.ac.th/index.php/wjst/article/view/4562>. Accessed: Jun. 12, 2020.

BORTOLINI, F. et al. Behaviour of alcoholic and acetic fermentations of kiwi mashes (Actinidia deliciosa); composition of mashes and production methods. Ciência e Tecnologia de Alimentos, v.21, n.2, p.236-243, 2001. Available from: <http:// dx.doi.org/10.1590/S0101-20612001000200020>. Accessed: Jun. 01, 2020. doi: 10.1590/S0101-20612001000200020.

BRAMONT, W. B. et al. Comparison of the centesimal, mineral and phytochemical composition of pulps and peel of ten different fruits. Revista Virtual de Química, v.10, n.4, 2018. Available from: $<$ http://static.sites.sbq.org.br/rvq.sbq.org.br/pdf/BramontNoPrelo. pdf $>$. Accessed: Jun. 06, 2020.

BRASIL. Ministério da Agricultura, Pecuária e Abastecimento. Decreto 6.871/2009 de 04/06/2009. Dispõe sobre a padronização, a classificação, o registro, a inspeção, a produção e a fiscalização de bebidas. Diário Oficial da União, Brasília, DF, 2009a Available from: <http://www.planalto.gov.br/ccivil_03/_Ato2007$2010 / 2009 /$ Decreto/D6871.htm\#: : text $=$ DECRETO $\% 20$ N\%C2\%BA\%206.871\%2C\%20DE\%204,que\%201he\%20 confere $\% 20 \mathrm{o} \% 20$ art $>$. Accessed: Feb. 25, 2020.

BRASIL, Ministério da Agricultura, Pecuária e Abastecimento. Decreto $\mathrm{n}^{\circ}$ 6.871, de 2009 Estabelece os parâmetros analíticos e quesitos complementares aos padrões de identidade e qualidade da polpa de fruta. Diário Oficial da União, Brasília, DF, 2009b. Available from: <http://www.in.gov.br/materia//asset_publisher/ Kujrw0TZC2Mb/content/id/44304943/do1-2018-10-08-instrucao normativa-n-37-de-1-de-outubro-de-2018-44304612>. Accessed: May, 15, 2019.

BRASIL, A. S. et al. Avaliação da qualidade físico-química de polpas de fruta congeladas comercializadas na cidade de Cuiabá- 
MT. Revista Brasileira de Fruticultura, v.38, n.1, p.167-175, 2016. Available from: <http://dx.doi.org/10.1590/0100-2945253/14>. Accessed: Jun. 01, 2020. doi: 10.1590/0100-2945-253/14.

BRASIL. Ministério da Agricultura, Pecuária e Abastecimento. Instrução Normativa 06/2012 de 03/04/2012. Estabelece os padrões de identidade e qualidade e a classificação dos fermentados acéticos. Diário Oficial da União, Brasília, DF, 2012a. Available from: <http://www.lex.com.br/legis_23137023_INSTRUCAO_ NORMATIVA_N_6_DE_3_DE_ABRIL_DE_2012.aspx $>$. Accessed: Apr. $\overline{28}, \overline{2019}$.

BRASIL. Ministério da Agricultura, Pecuária e Abastecimento. Instrução Normativa 34/2012. Estabelece, na forma desta Instrução Normativa e das tabelas $1,2,3,4,5,6,7,8$ e 9 constantes do seu Anexo I, a complementação dos padrões de identidade e qualidade para as seguintes bebidas fermentadas. Diário Oficial da União, Brasília, DF, 2012b. Available from: <http://www.agricultura. gov.br/assuntos/vigilancia-agropecuaria/ivegetal/bebidasarquivos/in-no-34-de-29-de-novembro-de-2012.pdf/view $>$. Accessed: Feb. 25, 2020.

CAC. Codex alimentarius commission. Proposed draft revised regional standard for vinegar, Italia, 2000.

CALLEJÓN, R. M. et al. Volatile compounds in red wine vinegars obtained by submerged and surface acetification in different woods. Food Chemistry, v.113, p.1252-1259, 2009. Available from: $<$ https://doi.org/10.1016/j.foodchem.2008.08.027>. Accessed: Apr. 28, 2020. doi: 10.1016/j.foodchem.2008.08.027.

CARDOSO, L. M. et al. Mangaba (Hancornia speciosa Gomes) from the Brazilian Cerrado: nutritional value, carotenoids and antioxidant vitamins. Fruits, v.69, p.89-99, 2014. Available from: $<$ https://doi.org/10.1051/fruits/2013105>. Accessed: Jun. 01, 2020. doi: $10.1051 /$ fruits/2013105.

CARNELOSSI, M.A. G. et al. Postharvest conservation of mangaba (Hancornia speciosa Gomes). Ciência e Agrotecnologia, v.28 n.5, p.1119-1125, 2004. Available from: <https://doi.org/10.1590/ S1413-70542004000500021>. Accessed: Jun. 01, 2020. doi: $10.1590 / \mathrm{S} 1413-70542004000500021$.

CASALE, M. et al. Study of the aging and oxidation processes of vinegar samples from different origins during storage by nearinfrared spectroscopy. Analytica Chimica Acta, v.557, p.360-366, 2006. Available from: $<$ https://doi.org/10.1016/j.aca.2005.10.063>. Accessed: Jun. 06, 2020. doi: 10.1016/j.aca.2005.10.063.

CEJUDO-BASTANTE, $C$. et al. Chemical and sensory characteristics of orange based vinegar. Journal Food Science Technology, v.53, n.8, p.3147-3156, 2016. Available from: $<$ https://doi.org/10.1007/s13197-016-2288-7>. Accessed: Jun. 15, 2020. doi: 10.1007/s13197-016-2288-7.

CHAVES NETO, J. R. et al. Compostos fenólicos, carotenoides e atividade antioxidante em frutos de cajá-manga. Boletim do centro de pesquisa de processamento de alimentos, v.36 n.1, p.55-68, 2018. Available from: <http://dx.doi.org/10.5380/bceppa. v36i1.58610>. Accessed: Jun. 16, 2020. doi: 10.5380/bceppa. v36i1.58610.

CHEN, W. et al. Chemical stability of yellow pigment extracted from the flower bud of Sophora japonica L. (Huaimi). International Journal of Food Science and Technology, v.45, p.1666-1672, 2010. Available from: <https://doi.org/10.1 111/j.1365-2621.2010.02322.x>. Accessed: Jun. 07, 2020. doi: 10.1111/j.1365-2621.2010.02322.x.

CHITARRA, M. I. F.; CHITARRA, A. B. Pós-colheita de frutas e hortaliças: fisiologia e manuseio. 2 ed. Lavras-MG: UFLA, 2005. 785p.

COELHO, E. et al. Vinegar production from fruit concentrates: effect on volatile composition and antioxidant activity. Journal Food Science Technology, v.54, n.12, p.4112-4122, 2017. Available from: <https://doi.org/10.1007 / s13197-017-2783-5>. Accessed: Jun. 12, 2020. doi: 10.1007 / s13197-017-2783-5.

COLLADOS, A. et al. Applying food enzymes in the kitchen. International Journal of Gastronomy and Food Science, v.21, 100212, 2020. Available from: <https://doi.org/10.1016/j. ijgfs.2020.100212>. Accessed: Jun. 01, 2020. doi: 10.1016/j. ijgfs.2020.100212.

CUNHA, M. A. A. et al. Blackberry vinegar Produced By Successive Acetification Cycles: Production, Characterization And Bioactivity Parameters. Brazilian Archives of Biology and Technology, v.59, p.1-12, 2016. Available from: <http://dx.doi. org/10.1590/1678-4324-2016150136>. Accessed: Jun. 01, 2020. doi: 10.1590/1678-4324-2016150136.

DANTAS, R. L. et al. Perfil da qualidade de polpas de fruta comercializadas na cidade de Campina Grande/PB. Green Journal of Agroecology, and Sustainable Development, v.5, n.5, p.61-66, 2010. Available from: <https://www.gvaa.com.br/revista/index. php/RVADS/article/view/464>. Accessed: Jun. 01, 2020.

DAVIES, C. V. et al. Bioactive compounds and antioxidant activity analysis during orange vinegar production. Food Science and Technology, v.37, n.3, p.449-455, 2017. Available from: <http:// dx.doi.org/10.1590/1678-457X.20816>. Accessed: Mar. 16, 2020. doi: 10.1590/1678-457X.20816.

DHINGRA, D. et al. Dietary fibre in foods: a review. Journal Food Science and Technology, v.49, n.3, p.255-266, 2012. Available from: <https://doi.org/10.1007/s13197-011-0365-5>. Accessed: Jun. 28, 2020. doi: 10.1007/s13197-011-0365-5.

DIAS, R. D. et al. Vinegar production from Jabuticaba (Myrciaria jaboticaba) fruit using immobilized acetic acid bacteria. Food Technol Biotechnol, v.3, n.54, p.351-359, 2016. Available from: $<$ http://dx.doi.org/10.17113/ftb.54.03.16.4416>. Accessed: Jun. 01, 2020. doi: $10.17113 / \mathrm{ftb} .54 .03 .16 .4416$.

DONNA, L. D. et al. Vinegar production from Citrus bergamia by-products and preservation of bioactive compounds. European Food Research and Technology, 246, p.1981-1990, 2020. Available from: <https://doi.org/10.1007/s00217-020-03549-1>. Accessed: Oct. 18, 2020. doi: 10.1007/s00217-020-03549-1.

DUARTE, W. F. et al. Characterization of different fruit wines made from cacao, cupuassu, gabiroba, jaboticaba and umbu $>$. LWT - Food Science and Technology, v.43, p.1564-1572, 2010. Available from: <https://doi.org/10.1016/j.lwt.2010.03.010>. Accessed: Jun. 10, 2020. doi: 10.1016/j.lwt.2010.03.010.

DUBOIS, M. et al. Colorimetric method for determination of sugars and related substances. Analytical Chemistry, v.28, n.3, p.350-356, 1956. Available from: <https://doi.org/10.1021/ ac60111a017>. Accessed: Jun. 20, 2020. doi: 10.1021/ ac60111a017. 
DUTCOSKY, S. D. Análise Sensorial de Alimentos. $4^{\mathrm{a}}$ ed. revisada e ampliada; Ed.; Champagnat, Curitiba, PR, p.531, 2013.

EMBRAPA. Empresa Brasileira de Pesquisa Agropecuária. Comunicado técnico, 86. Protocolo para determinação de açúcares redutores pelo método de Somogyi-Nelson. 2013. Available from: $<$ https://ainfo.cnptia.embrapa.br/digital/bitstream/ item/81814/1/cot-86.pdf $>$. Accessed: Aug. 13, 2018

FDA. Food and Drug Administration. CPG Sec 525.825. Vinegar, definitions e adulteration with vinegar eels. Compliance Policy Guide. 1980. Available from: < https://www.fda.gov/regulatoryinformation/search-fda-guidance-documents/cpg-sec-525825vinegar-definitions-adulteration-vinegar-eels $>$. Accessed: Jun. 03,2020 .

FDA. Food and Drug Administration. Acetic acid - use in foods labeling of foods in which used. Compliance Policy Guide. 1989. Available from: $<$ http://www.fda.gov/ICECI/ComplianceManuals/ CompliancePolicyGuidanceManual/ucm074577.htm>. Accessed: Jun. 03, 2020.

FERNANDES, A. C. F. et al. Sensorial, antioxidant and antimicrobial evaluation of vinegars from surpluses of physalis (Physalis pubescens L.) and red pitahaya (Hylocereus monacanthus). Journal of the Science of Food and Agriculture, v.99, n.5, p.2267-2274, 2019. Available from: <https://doi. org/10.1002/jsfa.9422>. Accessed: Jun. 15, 2020. doi: 10.1002/ jsfa. 9422 .

FRANCO, G. Tabela de composição química dos alimentos. 9 ed. Rio de Janeiro: Atheneu, p.307, 1992.

FRALEY, C.; RAFTERY, A. E. Model-based Clustering, discriminant analysis, and density estimation. Journal of the American Statistical Association, v.97, n.458, p.611-631, 2002. Available from: <https://doi.org/10.1198/016214502760047131>. Accessed: Apr. 02, 2020. doi: 10.1198/016214502760047131.

GAMBARO,A. Projective techniques to study consumer perception of food. Current Opinion in Food Science, v.21, p.46-50. 2018. Available from: <https://doi.org/10.1016/j.cofs.2018.05.004> Accessed: Oct. 02, 2020. doi: 10.1016/j.cofs.2018.05.004

GANDA-PUTRA, G. P.; WARTINI, N. M. The change of characteristics and antioxidant activity of cocoa vinegar during fermentation of pulp liquids by adding tape yeast. American Journal of Agriculture and Forestry, v.7, n.6, p.270-276, 2019 Available from: <https://doi.org/10.11648/j.ajaf.20190706.14>. Accessed: Jun. 06, 2020. doi: 10.11648/j.ajaf.20190706.14.

GIUFFRÈ, A. M. et al. Vinegar production to valorise Citrus bergamia by-products. European Food Research and Technology, v.245, p.667-675, 2019. Available from: $<$ https://doi. org/10.1007/s00217-018-3189-y>. Accessed: Jun. 03, 2020. doi: $10.1007 / \mathrm{s} 00217-018-3189-\mathrm{y}$.

GOKIRMAKLI, Ç. et al. Antioxidant properties of strawberry vinegar. International Journal of Food Engineering, v.5, n.3, p.171-174, 2019. Available from: <https://doi.org/10.18178/ ijfe.5.3.171-174>. Accessed: Jun. 01, 2020. doi: 10.18178/ ijfe.5.3.171-174

GOMES, R. J. et al. Acetic acid bacteria in the food industry: systematics, characteristics and applications. Food Technology e Biotechnology, v.56, n.2, p.139-151, 2018. Available from: <https://doi.org/10.17113/ftb.56.02.18.5593>. Accessed: Jun. 01, 2020. doi: $10.17113 / \mathrm{ftb} .56 .02 .18 .5593$.

GONÇALVES, C. A. A. et al. Physical, chemico-physical, enzymatic and cell wall charazterization during the different development stages of the fig tree fruits. Ciência e Tecnologia de Alimentos, v.26, p.220-229, 2006. Available from: $<$ http://dx.doi. org/10.1590/S0101-20612006000100035>. Accessed: Jun. 16, 2020. doi: 10.1590/S0101-20612006000100035.

GUERRERO, M. I. et al. Multivariate characterization of wine vinegars from the south of Spain according to their metallic content. Talanta, v.45, p.379-386, 1997. Available from: <https:// doi.org/10.1016/S0039-9140(97)00139-2>. Accessed: Mar. 15, 2020. doi: 10.1016/S0039-9140(97)00139-2.

GUIMARÃES, A. G. et al. Qualidade físicas e químicas de morango passa em diferentes embalagens. Engenharia na agricultura, v.22, n.4, p.306-316, 2014. Available from: <https:// doi.org/10.13083/reveng.v22i4.554>. Accessed: May, 30, 2020. doi: $10.13083 /$ reveng.v22i4.554.

HO, C. W. et al. Varieties, production, composition and health benefits of vinegars: A review. Food Chemistry, v.221, p.1621-1630, 2017. Available from: <https://doi.org/10.1016/j. foodchem.2016.10.128>. Accessed: May, 23, 2020. doi: 10.1016/j. foodchem.2016.10.128

HONGYU, K. et al. Principal Component Analysis: theory, interpretations and applications. Engineering and Science, v.5, n.1, p.83-90, 2015. Available from: <https://doi.org/10.18607/ ES20164053>. Accessed: Apr. 02, 2020. doi: 10.18607/ES20164053.

HORNEDO-ORTEGA, R. et al. Influence of fermentation process on the anthocyanin composition of wine and vinegar elaborated from strawberry. Journal of Food Science, v.82, n.2, p.364-372, 2017. Available from: $<$ https://doi.org/10.1111/1750-3841.13624>. Accessed: Jun. 06, 2020. doi: 10.1111/1750-3841.13624.

IAL. Instituto Adolfo Lutz. Métodos físico-químicos para análise de alimentos. São Paulo: Instituto Adolfo Lutz, 2008. Available from: $<$ http://www.ial.sp.gov.br/resources/editorinplace/ial/2016_3_19/ analisedealimentosial_2008.pdf>. Accessed: Mar. 16, 2019.

ILHA, E. C. et al. Utilization of bee (Apis melifera) honey for vinegar production at laboratory scale. Acta Científica Venezolana, v.51, n.4, p.231-235, 2000. Available from: <https:// pubmed.ncbi.nlm.nih.gov/11460793/>. Accessed: Jun. 01, 2020.

JACKSON, R. S. Wine science: principles and applications. 3 ed. San Diego: Academic Press, p.751, 2008.

KADIROGLU, P. FTIR Spectroscopy for Prediction of Quality Parameters and Antimicrobial Activity of Commercial Vinegars with Chemometrics. Journal of the Science of Food and Agriculture, v.98, n.11, p.4121-4127, 2018. Available from: $<$ https://doi.org/10.1002/jsfa.8929>. Accessed: Jun. 16, 2020. doi: $10.1002 /$ jsfa. 8929 .

KAISER, H. F. The varimax criterion for analytic rotation in factor analysis. Psychometrika, v.23, p.187-200, 1958. Available from: $<\mathrm{http}$ ://cda.psych.uiuc.edu/psychometrika_highly_cited_articles/ kaiser 1958.pdf>. Accessed: May, 15, 2020.

KAWA-RYGIELSKA, J. et al. Bioactive compounds in cornelian cherry vinegars. Molecules, v.23, n.2, p.2-16, 2018. Available 
Elaboration of mangaba vinegar by semi-solid fermentation combined with enzymatic activity: chemical characterization and sensory... 16

from: <https://doi.org/10.3390/moléculas23020379>. Accessed: Aug. 07, 2019. doi: 10.3390/moléculas23020379.

LAWLESS, H. T., HEYMANN, H. Sensory evaluation of food: principles and practices, Springer Science, Business Media New York. 1999.

LEAL, R. C. et al. Physical and chemical parameters evaluation of graviola frozen pulp marketed in supermarkets of São Luis - MA. Caderno de Pesquisa, v.20, n.2, p.76-80, 2013. Available from: $<$ https://doi.org/10.18764/2178-2229.v20n2p76-80>. Accessed: Jun. 20, 2020. doi: 10.18764/2178-2229.v20n2p76-80.

LEONEL, M. et al. Production of ginger vinegar. Ciência e Agrotecnologia de Lavras, v.39, n.2, p.183-190, 2015. Available from: <https://doi.org/10.1590/S141370542015000200010>. Accessed: Jun. 03, 2020. doi: 10.1590/ S1413-70542015000200010.

LEONÉS, A. et al. Development of vinegar obtained from lemon juice: Optimization and chemical characterization of the process. LWT - Food Science and Technology, v.100, p.314-321, 2019 Available from: <https://doi.org/10.1016/j.lwt.2018.10.096>. Accessed: Jun. 01, 2020. doi: 10.1016/j.lwt.2018.10.096.

LIMA, J. P. et al. First evaluation of the antimutagenic effect of mangaba fruit in vivo and its phenolic profile identification. Food Research International, v.75, p.216-224, 2015a. Available from $<$ https://doi.org/10.1016/j.foodres.2015.05.045>. Accessed: Jun. 01, 2020. doi: 10.1016/j.foodres.2015.05.045.

LIMA, J. P. et al. Climacteric pattern of mangaba fruit (Hancornia speciosa Gomes) andits responses to temperature, Scientia Horticulturae, v.197, p.399-403, 2015b. Available from: <https:// doi.org/10.1016/j.scienta.2015.09.059>. Accessed: Feb. 15, 2020. doi: 10.1016/j.scienta.2015.09.059.

LIMA, L. L. A. et al. Mixed nectar of umbu (Spondias tuberosa Arr. Camera) and mangaba (Hancornia Speciosa Gomes): Elaboration and quality evaluation. Brazilian Journal of Food Technology, v.21, e2017034, 2018. Available from: <https://doi. org/10.1590/1981-6723.03417>. Accessed: Mar. 14, 2020. doi: $10.1590 / 1981-6723.03417$.

LIPS, J. M.; DUIVENVOORDEN, J. F. Regional patterns of well drained upland soil differentiation in the middle Caquetá basin of Colombian Amazonia. Geoderma, v.72, p.219-257, 1996. Available from: <https://www.sciencedirect.com/science/ article/pii/0016706196000274>. Accessed: Apr. 02, 2020. doi: 10.1016/0016-7061(96)00027-4.

LIU, Q. et al. Effects of mixed cultures of Candida tropicalis and aromatizing yeast in alcoholic fermentation on the quality of apple vinegar. Biotech, v.9, n.128, p.1-10, 2019. Available from: $<$ https://doi.org/10.1007/s13205-019-1662-3>. Accessed: Mar. 14, 2020. doi: $10.1007 / \mathrm{s} 13205-019-1662-3$

MACHADO, A. R. et al. Acetic fermentation process by submerged method: a preliminary study. Global Science and Technology, v.12, n.01, p.01-13, 2019. Available from: $<$ https://rv.ifgoiano.edu. br/periodicos/index.php/gst/article/view/1035/678>. Accessed: Jun. 04, 2020.

MARQUES, F. P. P. et al. Quality pattern and identity of commercial fruit and vegetable vinegar (acetic acid fermentation). Food Science and Technology, v.30, p.119-126, 2010. Available from:
<https://doi.org/10.1590/S0101-20612010000500019>. Accessed: Jun. 03, 2020. doi: 10.1590/S0101-20612010000500019.

MAS, A. et al. Acetic acid bacteria and the production and quality of wine vinegar. The Scientific World Journal, 2014. Available from: <https://doi.org/10.1155/2014/394671>. Accessed: Feb. 20, 2020. doi: 10.1155/2014/394671.

MOJSOV, K. D. et al. Enzymes and wine - the enhanced quality and yield. Advanced Technologies, v.4, n.1, p.94-100, 2015. Available from: <https://doi.org/10.5937/savteh1501094M> Accessed: Oct. 12, 2020. doi: 10.5937/savteh1501094M.

NARAIN, N. et al. Mangaba - Hancornia speciosa. Exotic Fruits, p.305-318, 2018. Available from: <https://doi.org/10.1016/B978 0-12-803138-4.00040-X>. Accessed: Jan. 15, 2020. doi: 10.1016/ B978-0-12-803138-4.00040-X.

NASCIMENTO, R. S. M. et al. Physical and physicochemical characterization of 'mangabeira' fruits (Hancornia speciosa Gomes) in Western Bahia. Revista Brasileira de Engenharia Agrícola e Ambiental, v.18, n.8, p.856-860, 2014. Available from: $<$ http://dx.doi.org/10.1590/1807-1929/agriambi.v18n08p856-860>. Accessed: Jun. 01, 2020. doi: 10.1590/1807-1929/agriambi. v18n08p856-860

OLIVEIRA, M. E. S. et al. Fruit wine produced from cagaita (Eugenia dysenterica DC) by both free and immobilised yeast cell fermentation. Food Research International, v.44, p.2391-2400, 2011. Available from: < https://doi.org/10.1016/j. foodres.2011.02.028>. Accessed: Nov. 15, 2019. doi: 10.1016/j. foodres.2011.02.028.

OBANDA, M.; OWUOR, P. O. Flavanol composition and caffeine content of green leaf as quality potential indicators of kenyan black teas. Journal of the Science of Food and Agriculture, v.74, n.2, p.209-215, 1997. Available from: <https:// doi.org/0.1002/(SICI) 1097-0010(199706)74:2<209::AIDJSFA789>3.0.CO;2-4>. Accessed: Jun. 20, 2020 doi: 10.1002/ (SICI)1097-0010(199706)74:2<209::AID-JSFA789>3.0.CO;2-4

OZEN, M. et al. Sour cherry (Prunus cerasus L.) vinegars produced from fresh fruit or juice concentrate: bioactive compounds, volatile aroma compounds and antioxidant capacities. Food Chemistry, v.309, 2019. Available from: <https://doi. org/10.1016/ j.foodchem.2019.125664>. Accessed: Feb. 23, 2020. doi: 10.1016/j.foodchem.2019.125664.

OZTURK, I. et al. Antioxidant, antimicrobial, mineral, volatile, physicochemical and microbiological characteristics of traditional home-made Turkish vinegars. LWT - Food Science and Technology, v.63, p.144-151, 2015. Available from: $<$ https://doi. org/10.1016/j.lwt.2015.03.003>. Accessed: Jun. 03, 2020. doi: 10.1016/j.lwt.2015.03.003.

PACHECO, S. et al. Adaptação do método de extração de carotenoides para escala de micro-extração. In: IV Reunião de Biofortificação, 2011, Teresina, Piauí. Available from: <https:// www.embrapa.br/busca-de-publicacoes/-/publicacao/916218/ adaptacao-do-metodo-de-extracao-de-carotenoides-para-escalade-micro-extracao>. Accessed: Dec. 20, 2019.

PAIVA, F. I. G. et al. Qualidade de tomate em função da salinidade da água de irrigação e relações $\mathrm{K} / \mathrm{Ca}$ via fertirrigação. Brazilian Journal of Irrigation and Drainage, v.23, n.1, p.168-163, 2018. Available from: <http://dx.doi.org/10.15809/ 
irriga.2018v23n1p180-193>. Accessed: May, 28, 2020. doi: 10.15809/irriga.2018v23n1p180.

PEREIRA, A. C. et al. Hancornia speciosa Gomes (Apocynaceae) as a potential anti-diabetic drug. Journal of Ethnopharmacology, v.161, n.23, p.30-35, 2015. Available from: <https://doi. org/10.1016/j.jep.2014.11.050>. Accessed: Aug. 15, 2019. doi: 10.1016/j.jep.2014.11.050.

PEREIRA, A. V. et al. Espécies nativas da flora brasileira de valor econômico atual ou potencial. Ministério do Meio Ambiente, Brasília, n.5, p.239, 2016. Available from: <https:// www.embrapa.br/busca-de-publicacoes/-/publicacao/1073295/ especies-nativas-da-flora-brasileira-de-valor-economico-atual-oupotencial-plantas-para-o-futuro-regiao-centro-oeste>. Accessed: Aug. 01, 2019

PERFEITO, D. G. A. et al. Mangaba (Hancornia speciosa Gomes) fruit characterization and study the pulp extraction processes. Revista de Agricultura Neotropical, v.2, n.3, p.1-7, 2015. Available from: <http://dx.doi.org/10.32404/rean.v2i3.269>. Accessed: Jun. 01, 2020. doi: 10.32404/rean.v2i3.269.

PINO, J. A. et al. Análisis de los compuestos volátiles en el vinagre de acerola mediante microextracción en fase sólida acoplada con cromatografía de gases-espectrometría de masas. Revista CENIC Ciências Químicas, v.50, n.1, p.33-40, 2019. Available from: $<$ https://ojs3.cnic.cu/index.php/RevQuim/article/view/284> Accessed: Jun. 01, 2020.

R Development Core Team. R: A language and environment for statistical computing. R Foundation for Statistical Computing, Vienna, Austria. 2016. Available from: <https://www.R-project. org/>. Accessed: Jul. 25, 2019.

RAMÍREZ, S. V. et al. Obtención de una bebida nutritiva a partir de las semillas de sacha inchic (Plukenetia volubilis L.). Revista de la Sociedad Química del Perú, v.83, n.3, p.274-281, 2017. Available from: <https://doi.org/10.37761/rsqp.v83i3.111>. Accessed: Jun. 20, 2020. doi: 10.37761/rsqp.v83i3.111.

RAMOS, E. M.; GOMIDE, L. A. M. Avaliação da Qualidade de Carnes - Fundamentos e Metodologias. Viçosa, MG: Editora UFV, 1 ed. p.599, 2007.

RATTNER, H. Produtividade e desenvolvimento. Revista de Administração de Empresas, v.7, n.25, 1967. Available from: <https://doi.org/10.1590/S0034-75901967000400002>. Accessed: Jun. 11, 2020. doi: 10.1590/S003475901967000400002 .

REIS, A. F.; SCHMIELE, M. Characteristics and potentialities of Savanna fruits in the food industry. Brazilian Journal of Food Technology, v.22, e2017150, 2019. Available from: $<$ https://doi. org/10.1590/1981-6723.15017>. Accessed: Jun. 06, 2020. doi: 10.1590/1981-6723.15017.

RIZZON, L. A.; MIELE, A. Evaluation of the cv. Cabernet sauvignon in the manufacture of red wine. Ciência e Tecnologia de Alimentos, v.22, n.2, p.192-198, 2002. Available from: $<$ https:// doi.org/10.1590/S0101-20612002000200015>. Accessed: May, 25, 2020. doi: 10.1590/S0101-20612002000200015.

RODA, A. et al. Metabolite profiling and volatiles of pineapple wine and vinegar obtained from pineapple waste. Food Chemistry v.229, p.734-742, 2017. Available from: $<$ https://doi.org/10.1016/j. foodchem.2017.02.111>. Accessed: Jun. 03, 2020. doi: 10.1016/j. foodchem.2017.02.111.

RODRIGUEZ-AMAYA, D. B. Advances in food carotenoid research: contribution of a Brazilian laboratory. Revista Instituto Adolfo Lutz, v.63, n.2, p.129-138, 2004. Available from: <https:// pesquisa.bvsalud.org/portal/resource/pt/lil-404791>. Accessed: Oct. 05, 2019.

RUFINO, M. D. S. M. et al. Bioactive compounds and antioxidant capacities of 18 non-traditional tropical fruits from Brazil. Food Chemistry, v.121, n.4, p.996-1002, 2010. Available from: <https:// doi.org/10.1016/j.foodchem.2010.01.037>. Accessed: Nov. 20 2019. doi: 10.1016/j.foodchem.2010.01.037.

RUIZ, M. V.; TAPIA, O. C. Bioquímica de los Processos Metabólicos. 3 ed. Barcelona, p.459, 2019.

SANTOS, F. A. et al. Potential of sugarcane straw for ethanol production. Química Nova, v.35, n.5, p.1004-1010, 2012. Available from: <https://doi.org/10.1590/S010040422012000500025>. Accessed: Aug. 16, 2019. doi: 10.1590/ S0100-40422012000500025.

SENGUN, I. Y.; KARABIYIKLI, S. Importance of acetic acid bacteria in food industry. Food Control, v.22, n.5, p.647-656, 2011 Available from: $<$ https://doi.org/10.1016/j.foodcont.2010.11.008>. Accessed: Jun. 01, 2020. doi: 10.1016/j.foodcont.2010.11.008.

SIEIRO, C. et al. Microbial Pectic Enzymes in the Food and Wine Industry. Food Industrial Processes - Methods and Equipment, 2012. Avaliable from: <http://dx.doi.org/10.5772/33403>. Accessed: Oct. 12, 2020. doi: 10.5772/33403.

SILVA, M. R. et al. Chemical characterization of native species of fruits from savanna ecosystem. Ciência Rural, v.38 n.6, p.17901793, 2008. Available from: <https://doi.org/10.1590/S010384782008000600051>. Access May, 17, 2019. doi: 10.1590/ S0103-84782008000600051.

SILVA, H. L. A., et al. Sodium reduction and flavor enhancer addition in probiotic prato cheese: Contributions of quantitative descriptive analysis and temporal dominance of sensations for sensory profiling. Journal of Dairy Science, v.101, p.8837-8846. 2018. Available from: <https://doi.org/10.3168/jds.2018-14819>. Accessed: Oct. 02, 2020. doi: 10.3168/jds.2018-14819.

SIQUEIRA, A. P. S. et al. Shelf life of mangaba endemic of the cerrado in different ripeness stages. Revista de Agricultura Neotropical, Cassilândia, v.5, n.3, p.91-96, 2018. Available from: $<$ https://periodicosonline.uems.br/index.php/agrineo/article/ view/1927>. Accessed: May, 15, 2020.

SONG, N. E. et al. Application of indigenous Saccharomyces cerevisiae to improve the black raspberry (Rubus coreanus Miquel) vinegar fermentation process and its microbiological and physicochemical analysis. Food Science and Biotechnology, v.28, p.481-489, 2018. Available from: $<$ http://dx.doi.org/10.1007/ s10068-018-0489-8>. Accessed: May, 15, 2020. doi: 10.1007/ s10068-018-0489-8.

SOUZA, J. L. U.; MONTEIRO, R. A. B. Fatores interferentes na fermentação alcoólica para produção de etanol. Cadernos de Pós-Graduação da FAZU, v.2, p.100-107, 2011. Available from: $\quad<$ https://www.fazu.br/ojs/index.php/posfazu/article/ viewFile/471/363>. Accessed: Jun. 01, 2020. 
SPINOSA, W. A. et al. Vinegar rice (Oryza sativa L.) produced by a submerged fermentation process from alcoholic fermented rice. Food Science and Technology, v.35, p.196-201, 2015. Available from: <http://dx.doi.org/10.1590/1678-457X.6605>. Accessed: Jun. 03, 2020. doi: 10.1590/1678-457X.6605.

SPINOSA, W. A. et al. Fermentation kinetics of rice syrup, with high content of dextrose equivalent, by saccharomyces cerevisiae and characterization of volatile compounds from wine. Journal of Food Processing and Preservation, v.40, p.1199-1205, 2016. Available from: <https://doi.org/10.1111/jfpp.12702>. Accessed: Jun. 19, 2020. doi: 10.1111/jfpp.12702.

SUN, D, W. Advances in Vinegar Production. Contemporary Food Engineering Series, LIM, S. J. et al. In: Chapter 1 - History and Current Issues of Vinegar. 3 ed. Florida NW: CRC Press, p. $502,2020$.

TANNER, F. W. The microbiology of foods. Illinois, E.U.A: Editora Garrard Press, 2 ed. p.1196, 1944

TESSARO, D. et al. Alcohol and acetic fermentation appraisal for vinegar production from orange juice. Acta Scientiarum Technology, v.2, n.32, p.201-205, 2010. Available from: <http:// dx.doi.org/10.4025/actascitechnol.v32i2.4275>. Accessed: Jun. 01, 2020. doi: 10.4025/actascitechnol.v32i2.4275.

TESFAYE, W. et al. Sensory evaluation of sherry wine vinegar. Journal of Sensory Studies, v.17, p.133-144, 2002. Available from: $\quad<$ https://doi.org/10.1111/j.1745-459X.2002.tb00338 $\mathrm{x}>$. Accessed: Jun. 18, 2020. doi: 10.1111/j.1745-459X.2002. tb00338.x.

TESFAYE, W. et al. Descriptive sensory analysis of wine vinegar: tasting procedure and reliability of new attributes. Journal of Sensory Studies, v.25, p.216-230, 2010. Available from: $<$ https:// doi.org/10.1111/j.1745-459X.2009.00253.x>. Accessed: Aug. 12, 2019. doi: 10.1111/j.1745-459X.2009.00253.x.

TUNGLAND, B. C.; MAYER, D. Nondigestible oligo- and polysaccharides (dietary fiber): their physiology and role in human health and food. Comprehensive Reviews in Food Science and Food Safety, v.3, p.90-109, 2002. Available from: <https://doi. org/10.1111/j.1541-4337.2002.tb00009.x>. Accessed: Jun. 01, 2020. doi: 10.1111/j.1541-4337.2002.tb00009.x.

TURHAN, E. Ü.; CANBAS, A. Chemical and sensory properties of vinegar from dimrit grape by submerged and surface method. GIDA, v.41, n.1, p.1-7, 2016. Available from: <https://doi. org/10.15237/gida.GD15043>. Accessed: Jun. 15, 2020. doi: 10.15237/gida.GD15043.
UBEDA, C. et al. Employment of different processes for the production of strawberry vinegars: Effects on antioxidant activity, total phenols and monomeric anthocyanins LWT - Food Science and Technology, v.52, p.139-145, 2013. Available from: $<$ https:// doi.org/10.1016/j.lwt.2012.04.021>. Accessed: Jun. 01, 2020. doi: 10.1016/j.1wt.2012.04.021.

UBEDA, C. et al. A comparative study on aromatic profiles of strawberry vinegars obtained using different conditions in the production process. Food Chemistry, v.192, p.10511059, 2016. Available from: <https://doi.org/10.1016/j. foodchem.2015.07.091>. Accessed: Jun. 15, 2020. doi: 10.1016/j. foodchem.2015.07.091.

UZUNER, S. \& CEKMECELIOGLU, D. Enzymes in the Beverage Industry. Enzymes in Food Biotechnology, p.29-43, 2019. Available from: <https://doi.org/10.1016/B978-0-12-8132807.00003-7>. Accessed: Oct. 12, 2020. doi: 10.1016/B978-0-12813280-7.00003-7.

VIEIRA NETO, R. D. Recomendações técnicas para o cultivo da mangabeira. Embrapa Tabuleiros Costeiros, Aracajú - SE n.20, p.5, 2001. Available from: <https://www.embrapa.br/ tabuleiros-costeiros/busca-de-publicacoes/-/publicacao/360210/ recomendacoes-tecnicas-para-o-cultivo-da-mangabeira $>$. Accessed: Nov. 14, 2019.

VIEIRA, M. C. et al. Mangabeira fruits (Hancornia Speciosa Gomez): A promising. Fruit of Brazil. Scientific Electronic Archives, v.10, n.2, p.45-55, 2017. Available from: <http://www. seasinop.com.br/revista/index.php?journal=SEA\&page $=$ article\& op=view\&path $\% 5 \mathrm{~B} \% 5 \mathrm{D}=354 \&$ path $\% 5 \mathrm{~B} \% 5 \mathrm{D}=\mathrm{pdf}>$. Accessed: Nov. 13, 2019.

XIA, K. et al. New insights into the mechanisms of acetic acid resistance in acetobacter pasteurianus using itraq-dependent quantitative proteomic analysis. International Journal of Food Microbiology, v.5, p.238-241, 2016. Available from: $<$ https://doi. org/10.1016/j.ijfoodmicro.2016.09.016>. Accessed: Jun. 03, 2020. doi: 10.1016/j.jifoodmicro.2016.09.016.

XU, Q. et al. Antioxidant activity of vinegar melanoidins. Food Chemistry, v.102, p.841-849, 2007. Available from: $<$ https://doi. org/10.1016/j.foodchem.2006.06.013>. Accessed: Jun. 06, 2020. doi: $10.1016 / j$.foodchem.2006.06.013.

ZHAO, C. et al. Chemical composition and antioxidant characteristic of traditional and industrial Zhenjiang aromatic vinegars during the aging process. Molecules, v.23, p.1-17, 2018. Available from: <https://doi.org/10.3390/molecules23112949>. Accessed: Nov. 15, 2019. doi: 10.3390/molecules23112949. 